\title{
The informal labour market in India: transitory or permanent employment for migrants?
}

\author{
Abu S Shonchoy ${ }^{2^{*}}$ and PN Raja Junankar ${ }^{1}$
}

\author{
* Correspondence: \\ parves.shonchoy@gmail.com \\ ${ }^{2}$ Institute of Developing Economies \\ - Japan External Trade Organization \\ (IDE-JETRO) and University of Tokyo, \\ Tokyo, Japan \\ Full list of author information is \\ available at the end of the article
}

\begin{abstract}
This paper studies the characteristics of the workers in the informal economy and whether internal migrants treat this sector as a temporary location before moving on to the organised or formal sector to improve their lifetime income and living conditions. We limit our study to the Indian urban (non-agricultural) sector and study the characteristics of the household heads that belong to the informal sector (self-employed and informal wage workers) and the formal sector. We find that household heads that are less educated, come from poorer households, and/or are in lower social groups (castes and religions) are more likely to be in the informal sector. In addition, our results show strong evidence that the longer a rural migrant household head has been working in the urban areas, ceteris paribus, the more likely that individual has moved out of the informal wage sector. These results support the hypothesis that, for internal migrants, the informal wage labour market is a stepping stone to a secured life in the formal sector.

JEL codes: $017 ; \mathrm{J} 15 ; \mathrm{J} 61 ; \mathrm{J} 42$.

Keywords: Informal labour markets; Migrant; Caste; Religion
\end{abstract}

\section{Introduction}

In most developing countries, there is a large sector of the economy that is called the informal sector or the unorganized sector. Employment in the informal labour market plays an important role in most developing economies. Very broadly, the informal labour market consists of workers in the informal sector, plus casual workers in the formal sector. The informal labour market is a very large part of the agricultural sector, but is also a significant part of the urban sector. There is a difference between employment in the formal sector and the informal sector in terms of the conditions of work, whether workers are subject to government taxes, have access to social security or insurance, are casual or contract workers, and whether or not they receive the minimum wages ${ }^{1}$.

The informal economy is a very important sector of the Indian economy. The National Council of Applied Economic Research estimates that the informal sector-"unorganized sector"-generates about $62 \%$ of GDP, $50 \%$ of national savings and $40 \%$ of national exports (ILO 2002), p. 30. In terms of employment, the informal economy provides for about $55 \%$ of total employment (International Labour Organisation 2002), p. $14^{2}$. Urban areas (especially large cities) attract numerous migrants from both the rural areas and from smaller urban towns and cities in the hope of a better life.

\section{Springer}

(c) 2014 Shonchoy and Junankar; licensee Springer. This is an Open Access article distributed under the terms of the Creative Commons Attribution License (http://creativecommons.org/licenses/by/2.0), which permits unrestricted use, distribution, and reproduction in any medium, provided the original work is properly credited. 
The Indian labour market can be conceived of as a segmented market. One segment is the formal sector composed of workers who have salaried work, good working conditions, and are employed in organised business. The other segment is the informal economy consisting of small self-employed traders and business people, and casual workers in the informal or formal sectors. Some individuals are born into wealthy families who own large businesses and hence are in the formal sector by right of birth. Others who are born with parents from the professional classes would almost certainly have education from good schools and universities, and have a network of contacts that would ensure their joining the ranks of the employed in the formal sector. Some individuals may have built up sufficient assets over time to set up small businesses and hence enter the formal sector. However, most workers in the formal sector enter the sector through their educational achievements, or by birth (children of rich people) and through social networks. For someone who comes from a disadvantageous background (either in terms of income or belonging to a socially backward caste or religion) the only way to enter the formal sector is via education in "good" schools ${ }^{3}$ or universities. Even with a good education, entry into the formal sector is often based on family connections. The Indian government has for some time had a policy of positive discrimination for the Dalits, and as a result they may have a higher probability of finding a job in the formal (government) sector. Migrants (especially from rural areas) who come into urban areas would likely have to work in the informal sector for some time before they build good networks enabling them to move into the formal sector.

The literature on the role of the informal sector in developing countries has oscillated between treating the informal sector as a backward sector that is holding back economic development to a dynamic sector that is helping to develop the economy rapidly without straining foreign currency balances and with relatively low demands for (real) capital goods (see Mazumdar (1976), Weeks (1975), Bromley (1978), Gerxhani (2004)) ${ }^{4}$. The informal sector is considered to be a pre-capitalist form of production compared to the formal sector which is a profit maximising capitalist sector. There is a large volume of literature on rural-urban migration (see, Harris and Todaro (1970)) that examines migrants arriving in the city and initially finding work in the informal sector, then moving on to better paid work in the formal sector. Fields (2009) developed an early model of the informal sector as a "way station" along the path toward a formal job in urban areas (De Mel et al. (2010)) which has been followed by others. This view of the informal sector as a temporary abode for migrants has been disputed (among others) by Mazumdar (1976). The debate has also ranged over whether informal sector workers are living in poor conditions with low incomes, or whether some of the informal sector workers are there out of choice and have a comfortable life (see Meng 2001, Perry 2007). Some individuals may have employment in the formal sector and work in the informal sector as well.

Given the setup of the urban labour market in India, some of the important issues to investigate are (1) whether individuals working in the informal sector are migrants and whether they move out of the informal sector into the formal sector after a few years; (2) whether they are from disadvantaged social and ethnic groups who do not have social networks to enter the formal sector; and finally (3) whether those with low levels of education and skills are unable to enter formal sector employment and have to find low paid works in the informal sector (Mitra $(2004,2008)$ ). 
This paper is interested in studying the characteristics of the workers in the informal economy and whether migrants treat this sector as a permanent base or only as a temporary location before moving on to the organised or formal sector to improve their lifetime income and lifestyle. We limit our study to the Indian urban (non-agricultural) sector and study the characteristics of the household heads that belong to the informal sector (self-employed and informal wage workers) and the formal sector. We find that members who come from the lower social groups (castes and religions) are more likely to be in the informal sector. We distinguish between migrants in urban location who came from rural areas and those who came from other urban areas. We find that rural migrant's likelihood of staying in the informal wage labour sector is inversely related to the length of time a rural migrant spends in an urban area.

In Section 2 below, we clarify the definition of informal labour markets and briefly review the literature; Section 3 provides a detailed discussion of the properties of the urban informal sector in India; Section 4 discusses the lexicographic preferences that people have over formal sector, self-employment, and informal wage labour; Section 5 sets up an econometric model for estimating the probability of working in the informal sector and provides some results, while Section 6 provides results using a multivariate logit model; Section 7 concludes with a summary of the results. In general, we find that the longer the duration of a migrant in the urban sector the more likely s/he will have moved out of the informal sector.

\section{The informal labour market: definitions and a review of some earlier studies}

In the developing country context, the informal sector is sometimes defined in terms of the activities of the enterprises (ILO, 1972) and sometimes in terms of the kind of work done by individuals as employees or as self-employed people (Hart, 1973). There exists great heterogeneity in informality: there is the "intra-firm margin where firms may be partly formal and partly informal, the inter-sectoral margin between formal and informal firms, and the inter-sectoral margin of formal and informal workers operating through the labour market" Perry et al. (2007).

The International Labour Organisation (1972) characterised the informal sector as:
(a) Ease of entry
(b) Reliance on indigenous resources
(c) Family ownership of enterprise
(d) Small scale of operation, often defined in terms of hired workers less than (say) ten
(e) Labour-intensive methods of production and adapted technology
(f) Skills acquired outside the formal school system
(g) Unregulated and competitive markets

Whereas the formal sector was characterised by:
(a) Difficult entry
(b) Frequent reliance on overseas resources
(c) Corporate ownership 
(d) Large scale of operation

(e) Capital-intensive and often imported technology

(f) Formally acquired skills, often expatriate

(g) Protected markets (through tariffs, quotas, and licenses)

Hart (1973) discussed the informal sector in terms of the working conditions of the individuals and whether they worked for wages with good conditions or informally as self-employed workers. Informal activities included:

(a) Farming, market gardening, self employed artisans, shoemakers, tailors, etc.

(b) Working in construction, housing, road building

(c) Small scale distribution, e.g. petty traders, street hawkers, etc.

(d) Other services, e.g. barbers, shoe-shiners etc.

(e) Beggars

(f) Illegal activities like drug pushing

Formal sector income earning activities included:

(a) Public sector wage earners

(b) Private sector wage earners (on permanent contracts, not casual workers)

Sengupta (2009), p. 3 defined the informal economy thus:

\subsection{Informal sector}

The unorganised sector consists of all unincorporated private enterprises owned by individuals or households engaged in the sale and production of goods and services operated on a proprietary or partnership basis and with less than ten total workers.

\subsection{Informal worker/employment}

Unorganised workers consist of those working in the unorganised sector or households, excluding regular workers with social security benefits provided by employers and the workers in the formal sector without any employment and social security benefits provided by employers.

\subsection{Informal economy}

The informal sector and its workers plus the informal workers in the formal sector constitute the informal economy.

\section{The Indian informal labour market: some background information}

A recent report of the National Commission for Enterprises in the Unorganised Sector by the Government of India (Sengupta 2009) found that $86 \%$ of the total employment in 2004-2005 was in the informal sector. Further, the agricultural sector consisted almost entirely of informal workers. The non-agricultural workers in the informal sector were $36.5 \%$ of the total, most of whom were self-employed. From 1999-2000 to 
2004-2005 most of the increase in employment in the formal sector consisted of informal workers (Sengupta 2009, p.14). The NSSO (2012), p ii document found that in 2009-2010 in the non-agriculture sector, nearly $71 \%$ of the workers in rural areas and $67 \%$ in urban areas worked in the informal sector. It found that the informal sector activities are concentrated mainly in the manufacturing, construction, wholesale and retail trades, and transport, storage and communication industries.

Our study used data from the India Human Development Survey (IHDS) 2005, conducted by the Inter-university Consortium for Political and Social Research, Ann Arbor, Michigan, USA. The survey is a nationally representative, multi-topic survey of 41,554 households in 1,503 villages and 971 urban neighbourhoods across India. The data set has detailed information on household employment by industry and occupation, and detailed information about household characteristics including age, education, ethnicity, religion, and migration status. In this study we have limited our analysis to workers in the urban sector who are not engaged in any agricultural activities.

Our data-set consisted of 12,056 heads of households for whom we had data on their age, education, marital status, gender, religion, caste, income source, assets, migration status and years since migration into the urban sector.

We define the urban informal sector as artisans, petty traders, small business people (who do not hire any labour), and non-agricultural casual workers in the informal or formal sectors. The informal sector consists of the self-employed and informal wage labour. We define self-employment as petty traders who do not hire any workers and those in the organised trade/business category who do not hire any workers. Note that this is a stricter definition than that suggested by, for example, Sengupta (2009). The informal wage labour category covers those who are in the informal sector but are not self-employed, i.e., the artisans, and non-agricultural labourers who are casually employed. The formal sector consists of salaried employees, professionals, and organised trade/business people who hire workers. In our study we limited our analysis to only the heads of the representative households. The summary statistics of our sample is depicted in Table 1.

It is interesting to notice the industry and occupational distribution of the formal and informal sectors of the economy in our sample data (see Figure 1). Most of the informal wage labour is in manufacturing, construction, wholesale and retail trades, restaurants, and hotels, and in community, social and personal services. Self-employment is concentrated (not surprisingly) in the wholesale and retail trades, restaurants, and hotels. Informal wage labour is concentrated in occupations: production and related workers, transport equipment operators and labourers (presumably unskilled workers) (see Figure 2).

If we look at the distribution of migrants moving into these sectors, (see Figure 3) we find that $61 \%$ of the migrants work in the formal sector; almost $10 \%$ are self-employed entrepreneurs and $29 \%$ are informal wage workers.

A high proportion of migrants (28\%) are working primarily in the community, personal and social services, $23 \%$ in wholesale and retail trades, restaurants and hotels, and $28 \%$ in manufacturing (see Figure 4).

A high proportion of migrants (30\%) are employed as production and related workers, transport equipment operators and labourers while almost $29 \%$ are sales and service workers (see Figure 5). It is interesting to note that the main income source for migrants $(50.14 \%)$ is salaried employment; another $21.09 \%$ are in non-agricultural labour (see Figures 6). 
Table 1 Summary statistics

\begin{tabular}{|c|c|c|c|}
\hline & Formal & Informal & Total \\
\hline \multirow[t]{2}{*}{ Male } & 0.902 & 0.935 & 0.916 \\
\hline & $(0.297)$ & $(0.246)$ & $(0.277)$ \\
\hline \multirow[t]{2}{*}{ Rural to urban migration } & 0.283 & 0.246 & 0.267 \\
\hline & $(0.45)$ & $(0.431)$ & $(0.443)$ \\
\hline \multirow[t]{2}{*}{ Rural to urban migration duration } & 4.337 & 3.595 & 4.023 \\
\hline & $(9.077)$ & (8.355) & $(8.787)$ \\
\hline \multirow[t]{2}{*}{ Income (in Rupees) } & 103171.280 & 49812.840 & 80625.834 \\
\hline & $(124176.363)$ & $(51689.736)$ & $(103573.581)$ \\
\hline \multirow[t]{2}{*}{ Age } & 45.968 & 43.181 & 44.791 \\
\hline & $(11.936)$ & $(12.299)$ & $(12.169)$ \\
\hline \multirow[t]{2}{*}{ Size of the Household } & 4.842 & 5.066 & 4.937 \\
\hline & $(2.089)$ & $(2.089)$ & $(2.092)$ \\
\hline \multirow[t]{2}{*}{ Married } & 0.984 & 0.983 & 0.984 \\
\hline & $(0.124)$ & $(0.128)$ & $(0.126)$ \\
\hline \multirow[t]{2}{*}{ Primary Education } & 0.053 & 0.148 & 0.093 \\
\hline & $(0.223)$ & $(0.355)$ & $(0.290)$ \\
\hline \multirow[t]{2}{*}{ Secondary Education } & 0.168 & 0.301 & 0.224 \\
\hline & $(0.374)$ & $(0.459)$ & $(0.417)$ \\
\hline \multirow[t]{2}{*}{ Matriculation Complete } & 0.177 & 0.170 & 0.174 \\
\hline & $(0.382)$ & $(0.376)$ & $(0.379)$ \\
\hline \multirow[t]{2}{*}{ Tertiary Education } & 0.163 & 0.099 & 0.136 \\
\hline & $(0.370)$ & $(0.299)$ & $(0.343)$ \\
\hline \multirow[t]{2}{*}{ Graduate } & 0.399 & 0.123 & 0.283 \\
\hline & $(0.490)$ & $(0.328)$ & $(0.450)$ \\
\hline \multirow[t]{2}{*}{ Adivasi } & 0.041 & 0.024 & 0.033 \\
\hline & $(0.197)$ & $(0.152)$ & $(0.180)$ \\
\hline \multirow[t]{2}{*}{ Dalit } & 0.143 & 0.178 & 0.158 \\
\hline & $(0.350)$ & $(0.382)$ & $(0.365)$ \\
\hline \multirow[t]{2}{*}{ Muslim } & 0.108 & 0.218 & 0.154 \\
\hline & $(0.310)$ & $(0.413)$ & $(0.361)$ \\
\hline \multirow[t]{2}{*}{ Father's Occupation: Professional } & 0.111 & 0.056 & 0.089 \\
\hline & $(0.314)$ & $(0.230)$ & $(0.285)$ \\
\hline \multirow[t]{2}{*}{ Father's Occupation: Executive } & 0.030 & 0.010 & 0.022 \\
\hline & $(0.169)$ & $(0.098)$ & $(0.145)$ \\
\hline \multirow[t]{2}{*}{ Father's Occupation: Clerk } & 0.108 & 0.036 & 0.079 \\
\hline & $(0.311)$ & $(0.186)$ & $(0.270)$ \\
\hline \multirow[t]{2}{*}{ Father's Occupation: Sales } & 0.132 & 0.189 & 0.155 \\
\hline & $(0.338)$ & $(0.392)$ & $(0.362)$ \\
\hline \multirow[t]{2}{*}{ Father's Occupation: Service } & 0.113 & 0.085 & 0.102 \\
\hline & $(0.316)$ & $(0.279)$ & $(0.302)$ \\
\hline \multirow[t]{2}{*}{ Father's Occupation: Agro } & 0.352 & 0.341 & 0.347 \\
\hline & $(0.478)$ & $(0.474)$ & $(0.476)$ \\
\hline \multirow[t]{2}{*}{ Father's Occupation: Labourer } & 0.155 & 0.284 & 0.207 \\
\hline & $(0.362)$ & $(0.451)$ & $(0.405)$ \\
\hline
\end{tabular}


Table 1 Summary statistics (Continued)

\begin{tabular}{llll}
\hline Father's Education: Primary & 0.222 & 0.226 & 0.224 \\
Father's Education: Secondary & $(0.416)$ & $(0.418)$ & $(0.417)$ \\
& 0.236 & 0.140 & 0.196 \\
Father's Education: Tertiary & $(0.425)$ & $(0.347)$ & $(0.397)$ \\
Father's Education: Graduation & 0.050 & 0.014 & 0.035 \\
& $(0.218)$ & $(0.119)$ & $(0.184)$ \\
$N$ & 0.063 & 0.013 & 0.042 \\
\hline
\end{tabular}

The caste and religion breakdown for the formal and informal sectors (self-employed and informal wage labour) show interesting patterns. As one would suspect, Brahmins and people belong to high caste are more likely to be in the formal sector, compared to the lower social castes and Muslims. If we divert our attention to the distribution of people by caste and religion based on the principal source of household income, as depicted in Table 2, we see that Brahmins and people belong to high caste are more likely to be salaried workers or professionals, whilst Dalits and Muslims are more likely to be non-agricultural labourers or artisans (see Figure 7).

When we look at the distribution of occupations by caste and religion, as depicted in Table 3, we note that Brahmins and high caste people are more likely to be in the higher level occupations, while Dalits and Muslims are more likely to be in the lower level occupations.

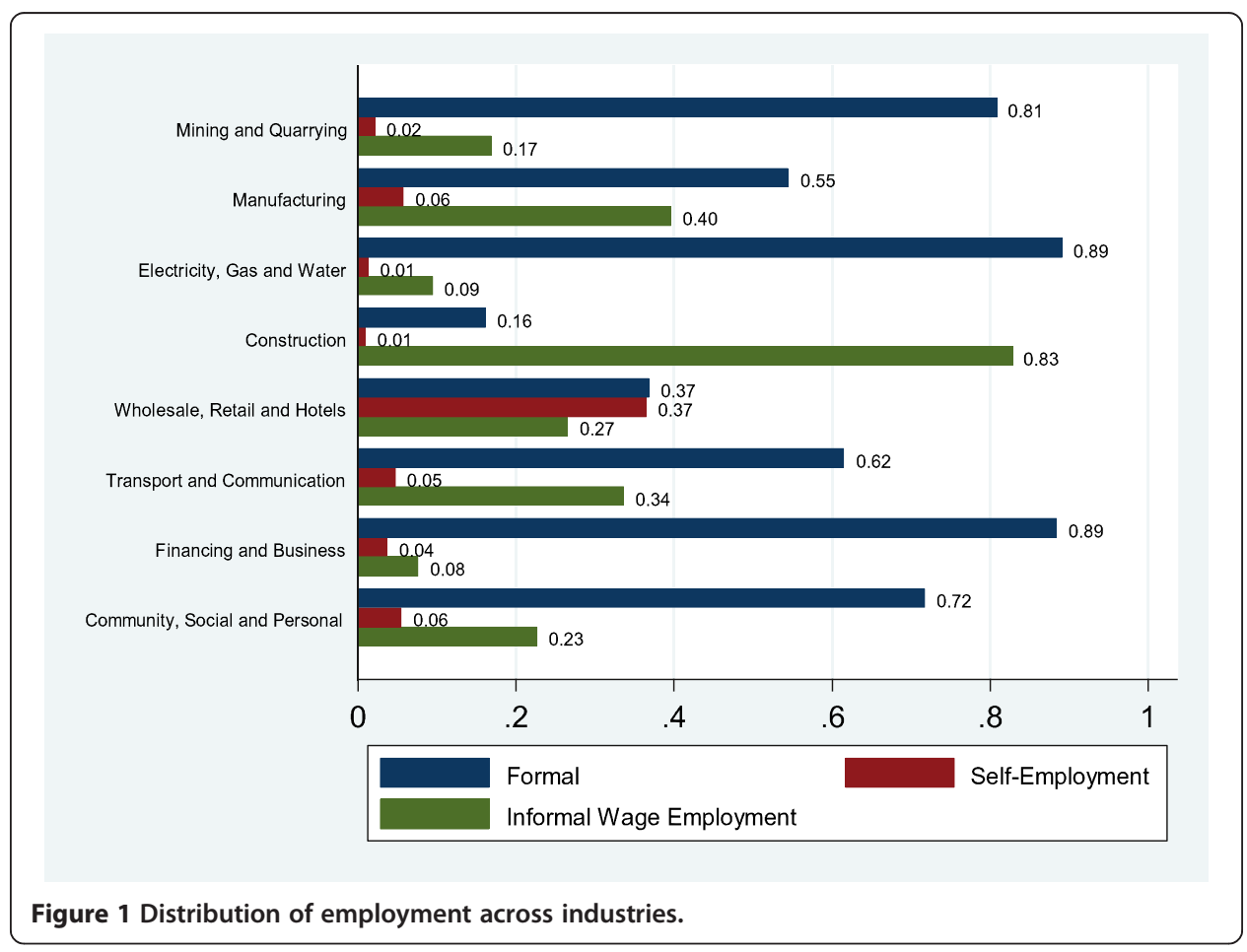



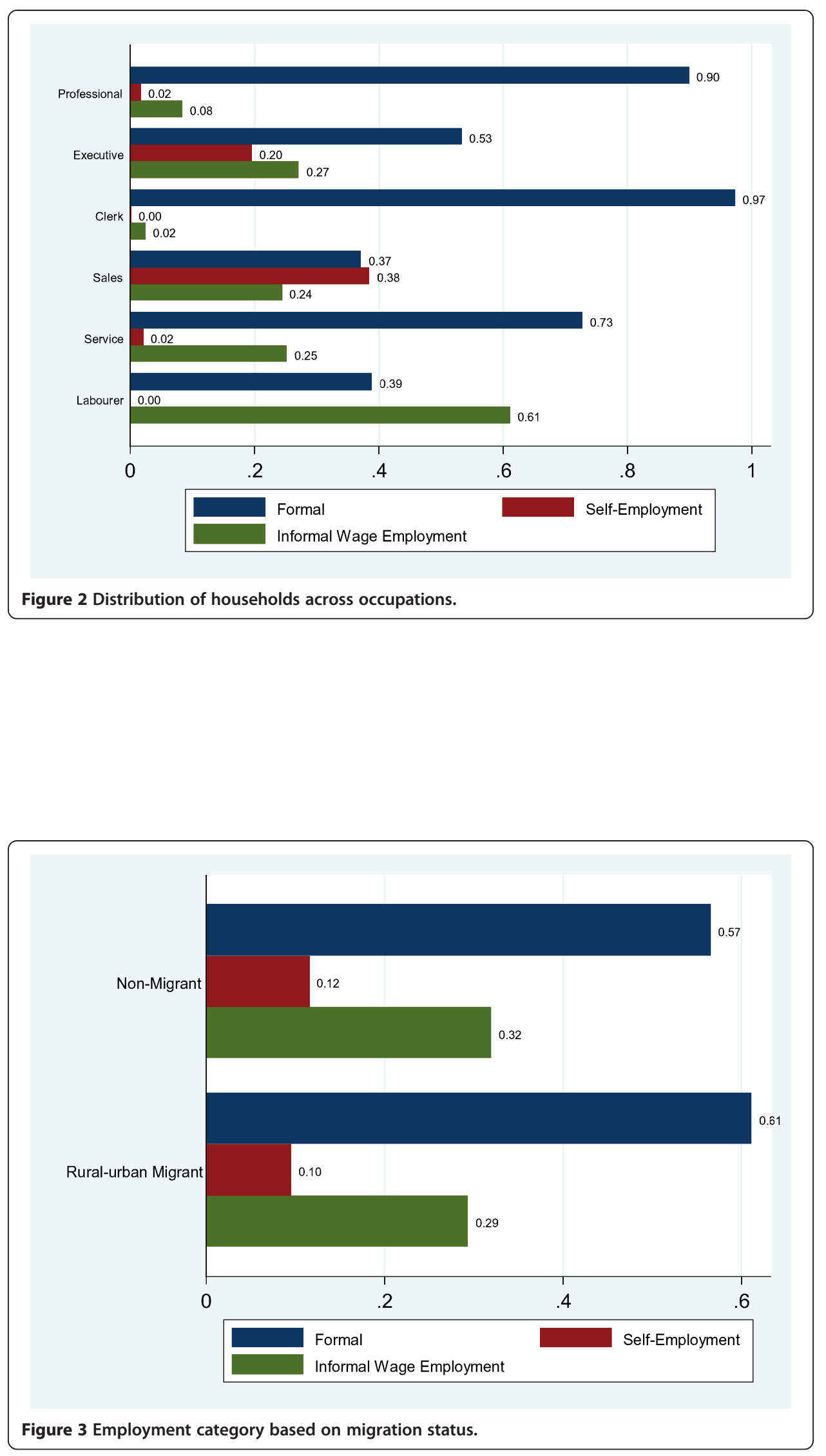

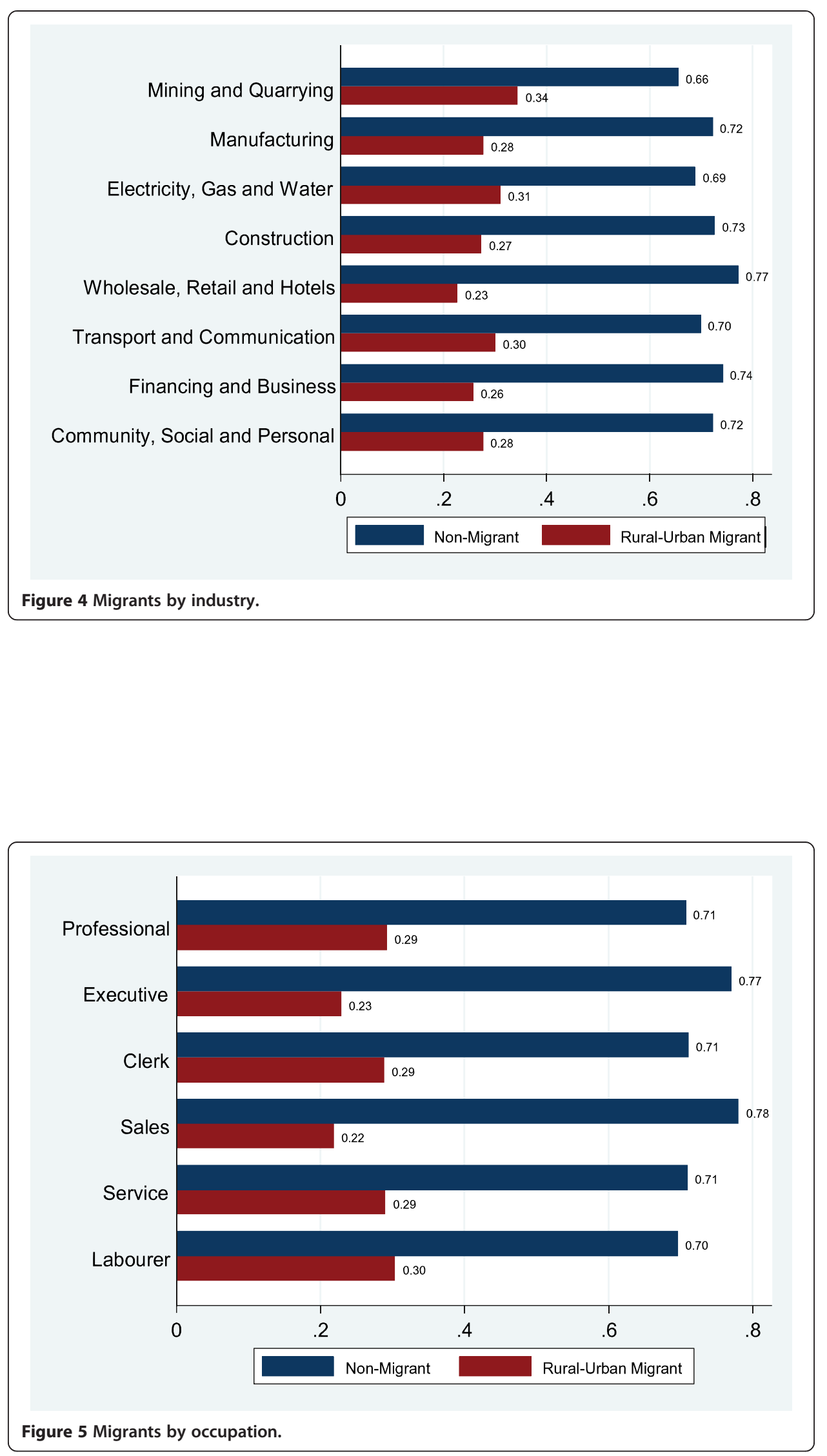


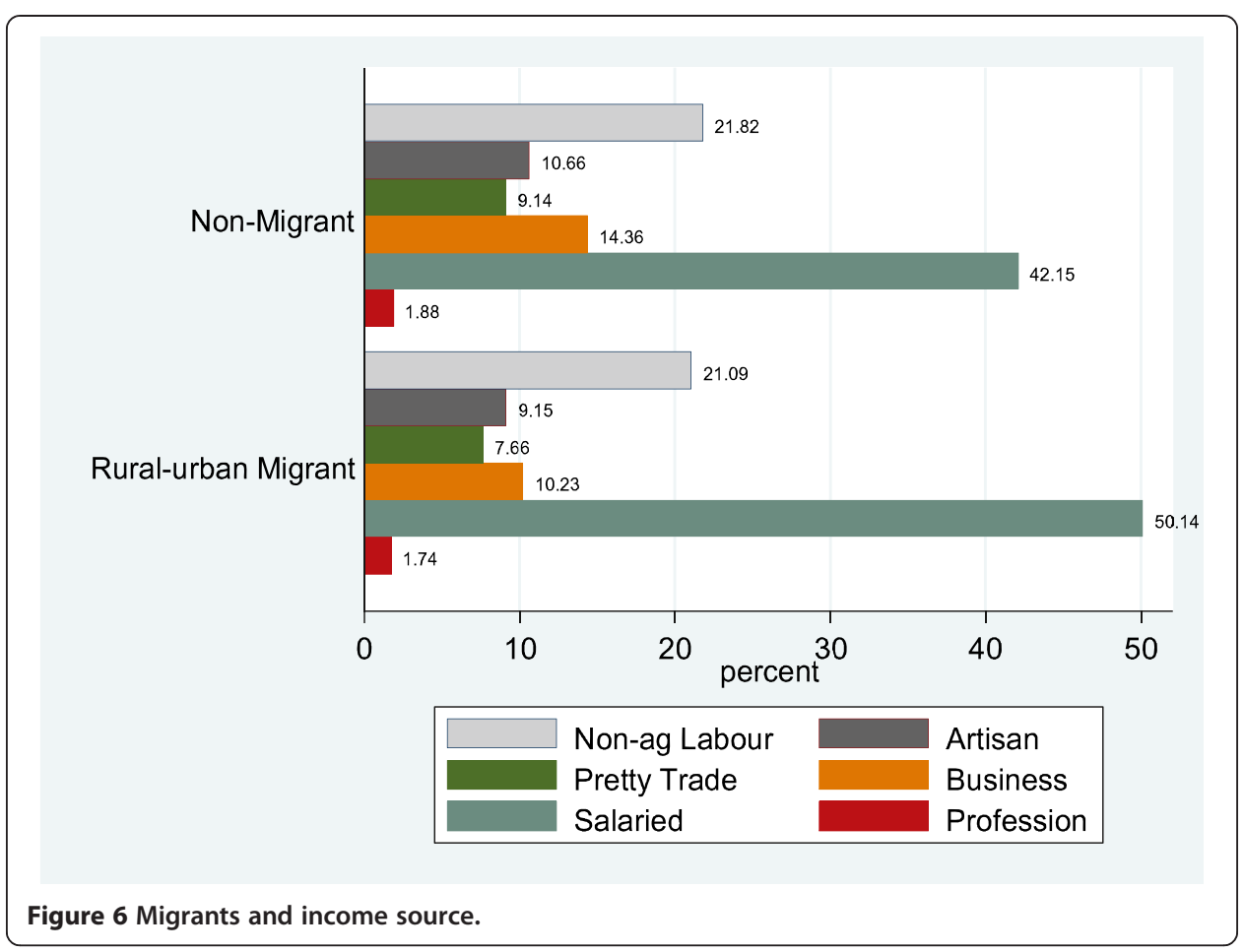

\section{The informal economy: some analytical features}

We assume that individuals would, in general, prefer to work in the formal sector, either as employees or as owners/managers ${ }^{5}$. This is based on the idea that the formal sector provides a better life not only in terms of present and future income, but also in terms of better working conditions (e.g., security of tenure, social security benefits, access to unions, safer working conditions). If they are unable to enter the formal sector, we assume that they would prefer to be self-employed (as long as their expected incomes are not below that in the informal wage sector). Employees in the informal wage sector would prefer to become self-employed if they have access to credit to set up small businesses. Many of them may simply be "waiting" for a job in the formal sector. In the Harris-Todaro model, rural migrants come to the urban areas as long as their expected wages (urban wage multiplied by the probability of finding a job) are greater

Table 2 Caste and religion by source of income

\begin{tabular}{llllllll}
\hline & Non-Ag labour & Artisan & Petty traders & Business & Salaried & Professionals & Total \\
\hline Brahmin & 56 & 67 & 68 & 136 & 705 & 43 & 1,075 \\
High caste & 254 & 182 & 277 & 536 & 1,429 & 59 & 2,737 \\
OBC & 875 & 437 & 341 & 446 & 1,438 & 56 & 3,593 \\
Dalit & 664 & 205 & 105 & 108 & 803 & 18 & 1,903 \\
Adivasi & 97 & 11 & 16 & 35 & 238 & 6 & 403 \\
Muslim & 598 & 295 & 211 & 256 & 471 & 29 & 1,860 \\
Sikh, Jain & 9 & 20 & 32 & 61 & 129 & 5 & 256 \\
Christian & 54 & 19 & 4 & 20 & 126 & 6 & 229 \\
Total & $\mathbf{2 , 6 0 7}$ & $\mathbf{1 , 2 3 6}$ & $\mathbf{1 , 0 5 4}$ & $\mathbf{1 , 5 9 8}$ & $\mathbf{5 , 3 3 9}$ & $\mathbf{2 2 2}$ & $\mathbf{1 2 , 0 5 6}$ \\
\hline
\end{tabular}

Source: India Human Development Survey. 


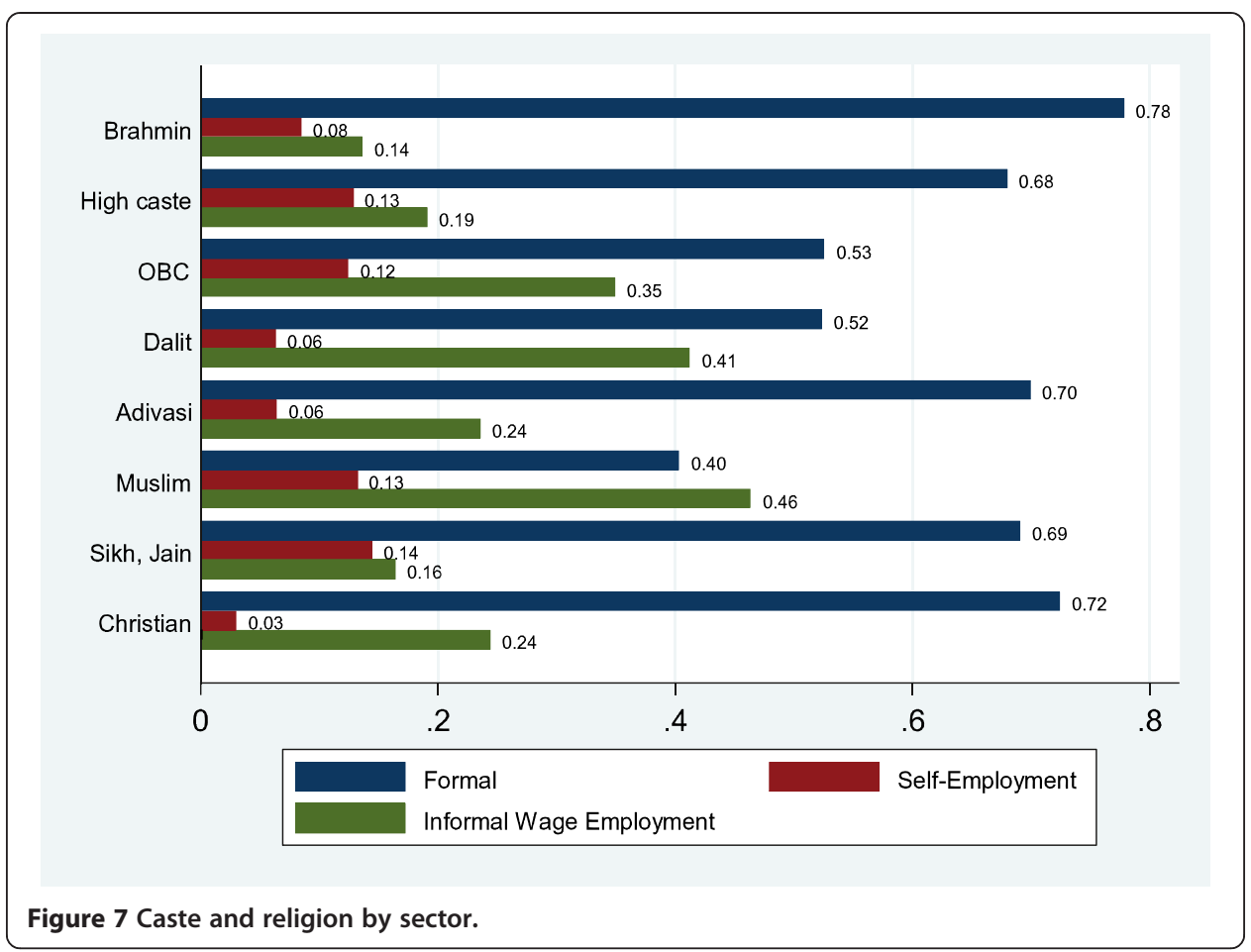

than their rural subsistence wage. Migrants who do not find work in the urban formal sector then enter the urban informal sector which is meant to be a form of "wait unemployment"6. Essentially, we are arguing that individuals have lexicographic preferences over these choices. However, what we observe is a reduced form depending on the household head's choice and success in the formal labour market, and the constraints in the credit market that determine whether s/he can become self-employed. Informal wage labour then is a residual category.

In fact if we look at the actual income (based on our sample), we find that the incomes of these three groups overlap to some extent, with the lowest income being in informal wage labour, followed by self-employment, followed by formal sector income. Figure 8 presents the kernel densities of the logs of informal wage labour, informal self-

Table 3 Caste and religion by occupation

\begin{tabular}{|c|c|c|c|c|c|c|c|c|c|}
\hline & Brahmin & $\begin{array}{l}\text { High } \\
\text { caste }\end{array}$ & OBC & Dalit & Adivasi & Muslim & $\begin{array}{l}\text { Sikh, } \\
\text { Jain }\end{array}$ & Christian & Total \\
\hline $\begin{array}{l}\text { Professions, Technical and } \\
\text { Related Workers }\end{array}$ & 195 & 280 & 245 & 105 & 49 & 72 & 27 & 22 & 995 \\
\hline $\begin{array}{l}\text { Administrative, Executive } \\
\text { and Managerial Workers }\end{array}$ & 135 & 357 & 427 & 147 & 28 & 243 & 35 & 27 & 1,399 \\
\hline Clerical and Related Workers & 188 & 329 & 361 & 191 & 50 & 84 & 23 & 24 & 1,250 \\
\hline Sale Workers & 190 & 746 & 765 & 235 & 52 & 445 & 97 & 21 & 2,551 \\
\hline Service Workers & 71 & 172 & 210 & 248 & 44 & 87 & 11 & 18 & 861 \\
\hline $\begin{array}{l}\text { Production, Transport } \\
\text { and Labourers }\end{array}$ & 159 & 551 & 1,236 & 799 & 141 & 732 & 41 & 67 & 3,726 \\
\hline Missing & 137 & 302 & 349 & 178 & 39 & 197 & 22 & 50 & 1,274 \\
\hline Total & 1,075 & 2,737 & 3,593 & 1,903 & 403 & 1,860 & 256 & 229 & 12,056 \\
\hline
\end{tabular}

Source: India Human Development Survey. 


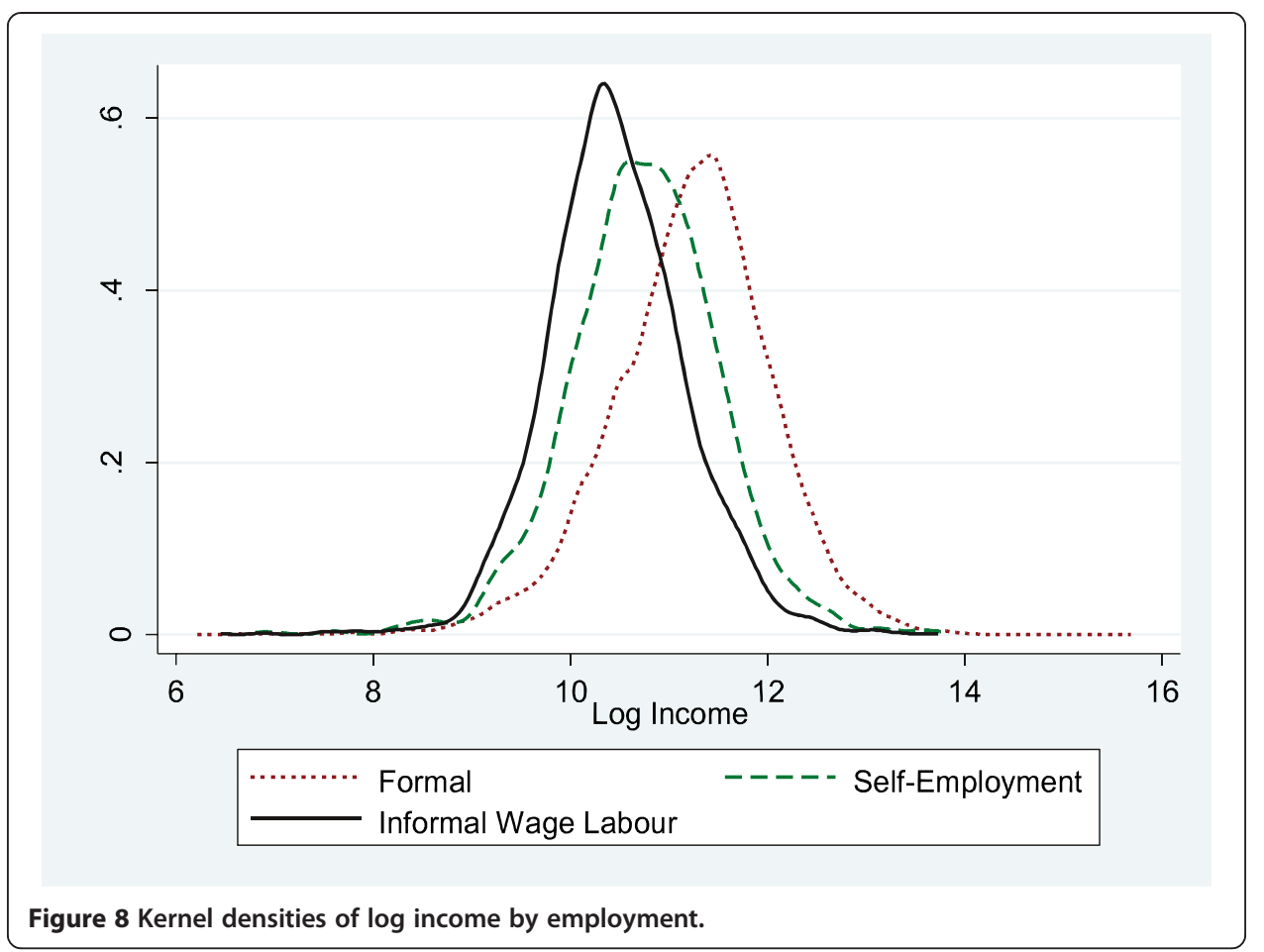

employment, and formal income respectively. As can be seen, informal wage-labour income is distributed to the left, informal self-employment income is in the middle, and formal income is to the right of the other distributions. There is some overlap at the lower tails of the distributions, but self-employment and formal incomes have tails spread out at the higher income levels ${ }^{7}$.

A Kolmogorov-Smirnov test reveals that there are significant differences in these kernel densities. (All pair-wise Kolmogorov-Smirnov tests are statistically significant with a $\mathrm{p}$-value of 0.000 ). Table 4 provides some summary statistics to illustrate the differences in the distribution of incomes. As discussed above, the mean (log) income in the formal sector is greater than that for the self-employed and that is greater than that for informal wage labour. The only curious result seems to be that the minimum of the formal sector is lower than that of the other two groups.

To be in the formal sector, domestic capitalists need to have significant amounts of capital and access to credit. Inheritance plays a large part in providing either the original capital or access to credit. Multinationals come in with large amounts of capital with technology that is labour saving (embodied technological change). Employment in the formal sector is then limited by the use of imported technology and limited amounts of capital. Note that only a limited amount of labour-capital substitution is possible because of embodied technology.

Table 4 Distribution of log incomes by sector

\begin{tabular}{llllll}
\hline Variable: log of income & Obs. & Mean & Std. Dev. & Min & Max \\
\hline Formal & 6916 & 11.2313 & 0.81603 & 6.21461 & 15.6904 \\
Self-employment & 1324 & 10.7466 & 0.76783 & 6.8024 & 13.7695 \\
Informal wage labour & 3744 & 10.4617 & 0.70924 & 6.44883 & 13.731 \\
\hline
\end{tabular}

Source: India Human Development Survey. 
Wages in the formal sector are fixed by the government (minimum wages), by unions or employers using efficiency wage ideas, or by multinational firms that constrain wages. Employers in the formal sector ration employment by using education/experience as an index of productivity, and using religion/caste as a signal for productivity (statistical discrimination). Given two people with the same education/skill levels, they would prefer a high caste Hindu to a low caste Hindu or a Muslim. Note: being in the formal economy is not a guarantee against poverty see (ILO 2002), p.31.

Informal sector employment is a residual; the lower the employment in the formal sector, the greater the number who look for work in the informal sector, and hence, the lower the wages (income) for this sector.

Figure 9 below shows that $43 \%$ of the self-employed have taken out loans for business purposes, compared to only $14 \%$ in the formal sector and $16 \%$ in the informal wage labour group. It is clear that the self-employed have to take out loans for setting up and running a small enterprise. Presumably many of the informal wage workers would be interested in setting up a small business but are unable to access credit.

To summarise this section, we argue that households have a lexicographic preference ordering over the different outcomes, formal, self-employment, or informal wage labour. Migrants, especially rural migrants, have little access to credit or to the formal labour market, at least until they have spent some years in the urban sector.

\section{Probability of working in the informal sector}

In this section we estimate the probability of a household head working in the informal wage employment sector to be self-employed or in the formal sector. As discussed earlier, we make three hypotheses. One is that those households that come from the

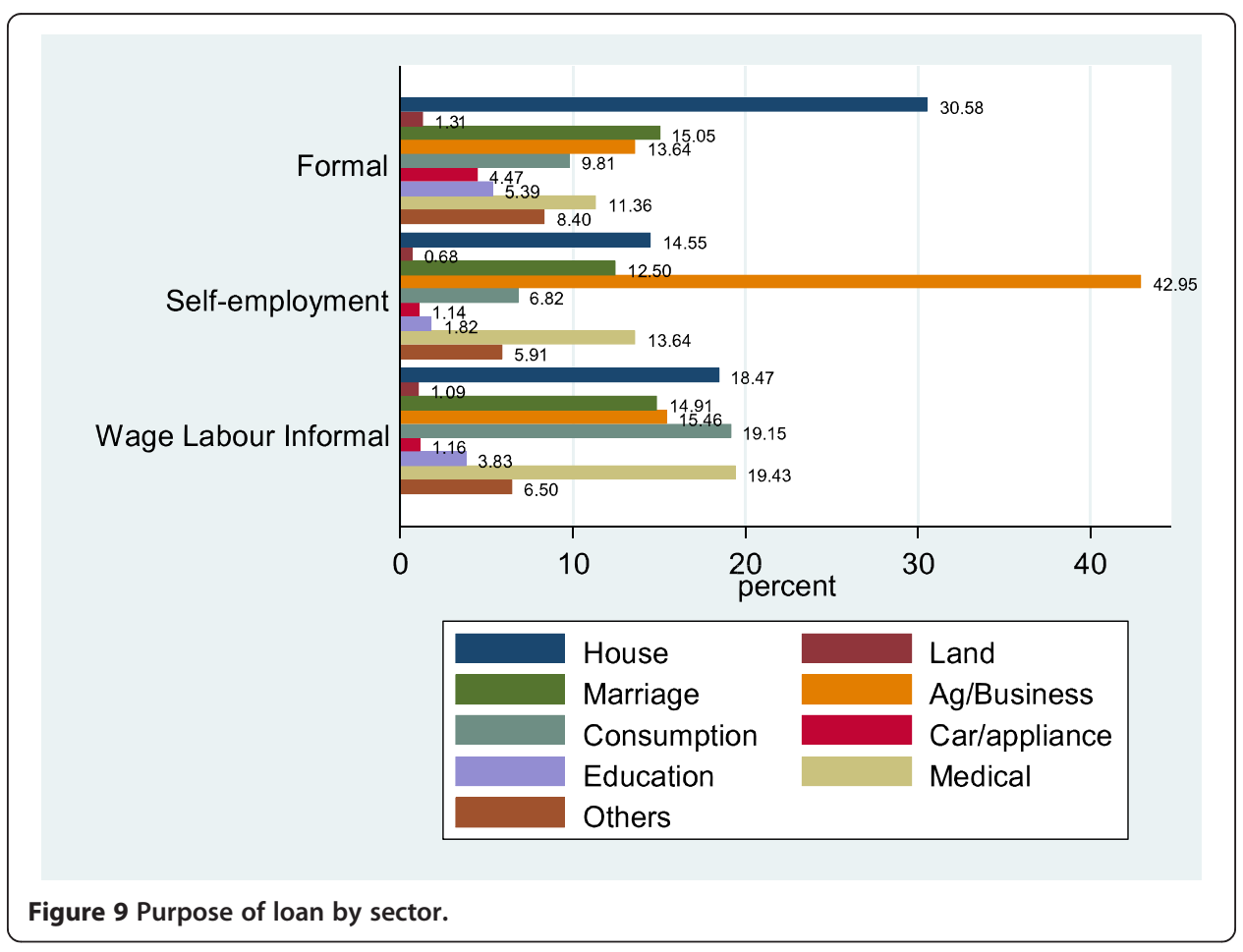


lower social classes/groups are more likely to be working in the informal sector. Some of these households may have the entrepreneurial skills or have access to small amounts of capital to set up as self-employed workers. We also hypothesise that households coming from higher social classes/groups, and/or that have higher levels of education are more likely to be working in the formal sector. Further we hypothesise that migrants who come into the urban areas would initially find employment in the informal sector and after some time, when they have accumulated sufficient funds or developed social networks or skills, are more likely to move into the formal sector. In our analysis below we regard migrants as those whose origin is in a rural area. Individuals who have come from other urban areas are regarded as "urban natives". We hypothesise that the duration of migration from a rural origin influences the sector of employment.

\subsection{Econometrics and identification strategy}

The fundamental challenge of estimating the causal impact of migration duration on the probability of working in the informal sector is the possibility of unobserved individual characteristics that might influence the migration decision, survival in a migration destination, and the duration as well as the likelihood of working in the informal sector. For example, it might be possible that individuals with unobserved high ability or entrepreneurial skills might opt to move out of the rural area early in their life and remain in the urban area, and such unobserved skills and ability will also influence their choice of sector in the migration destination. Without controlling for this, estimation may be biased and inconsistent.

If we had panel data, we could have used methods to control for individual heterogeneity. Another ideal method that could be used to disentangle such unobserved influences on migration duration and job status would be by using some natural experimental framework or by randomly inducing people to migrate out of rural areas to estimate the causal impact of migration on job choice. Lacking the availability of such methods, we need to opt for an instrumental variable approach (IV) where we can instrument migration duration with a set of variables which do not have a direct influence on job placement or current job status.

One recent method to instrument for migration is using the historic migration rate as an instrument for current migration status for example see, (Woodruff and Zenteno (2007), Hanson and Woodruff (2003); McKenzie and Rapoport (2007, 2011); LópezCórdoba (2005); and Hildebrandt and McKenzie (2005)). Following the methodology of these influential works, we have used the historic state-level migration rates as an instrument for current migration duration. In particular, we use the Indian migration rates from data collected in the 1991 census at the state level and use this variable as an instrument in which the household is currently located.

It can be argued that these historic migration rates are the result of the massive development of railroads and other transportation systems in India coupled with the rapid economic expansion of large cities which created extended job demand. These historic migration rates can also be considered as signals of migration friendliness, of strong migration networks that can effectively lower the cost of migration for future potential migrants and increase the chances of their survival. These signals and networks become 
self-perpetuating, and as a result, continue to influence the migration decisions of households today.

Our identifying assumption is that historic state-level migration rates do not affect the current job placement of the individuals, apart from their influence through current migration. Instrumental variables estimation relies on this exogeneity assumption, and so it is important to consider and counteract potential threats to its validity.

One potential threat is that the historic level of inequality and lower economic class (lower caste and religious groups) could induce the historic migration rate, and that they are also influencing the current rate due to intergenerational transition. To tackle these potential pitfalls, we also used interaction terms of historic migration rate with the caste dummies as additional instruments. We have also controlled for city, district and state level fixed effects to control for spatial differences and location preferences, and report our results based on robust standard errors clustered at the individual level.

An alternative set of instruments would be to use the state level growth rates of GDP as this would capture the potential pull factor of migration ${ }^{8}$. The idea of this instrumental variable is deep-rooted in the history of Indian economic development and generated with the aim to capture the post-liberalization of India in 1992. Since statelevel GDP has large heterogeneity, migration decisions of individuals would be based on comparing likely destinations with income potentialities, therefore could act as an instrument. As a robustness check, we have reported regression estimates based on the alternative instrumental variable in all result tables. To increase the precision of our estimation, we also estimated the equations using the additional set of instruments by employing the state-level GDP growth rate of India in 1994 interacted with caste dummies.

As our main outcome of interest is whether migrants use the informal sector as their temporary base (like a stepping stone), we studied the impact of migration duration of individuals on their placement in the informal sector. The reduced form IV approach consists of estimating a two-stage model of the following form, where $I_{j}$ is the outcome variable of interest (individual j's current employment sector), $M_{j k}$ is individual $j$ 's migration duration, and who is currently staying in State $k$ (years of migration since originally migrating), and $Z_{k}$ is the set of instrumental variables. Hence the reducedform first stage equation for migration $M_{j k}$, following Amemiya (1978), would be:

$$
\begin{aligned}
& M_{j k}^{*}=\beta_{0}+\beta_{1} Z_{k}+\beta_{2} X_{j k}+\gamma_{k}^{m}+\epsilon_{j k}^{m}, \\
& M_{j k}=\left\{\begin{aligned}
M_{j k}, & \text { if } M_{j k}^{*}>M_{0} \\
0, & \text { if } M_{j k}^{*} \leq M_{0},
\end{aligned}\right.
\end{aligned}
$$

and the equation for employment in the informal sector $I_{j k}$ is

$$
\begin{aligned}
& I_{i k}^{*}=\alpha_{0}+\alpha_{1} M_{j k}+\beta_{2} X_{j k}+\gamma_{k}^{i}+\epsilon_{j k}^{i}, \\
& I_{j k}= \begin{cases}1, & \text { if } I_{j k}^{*}<I_{0} \\
0, & \text { if } I_{j k}^{*} \geq I_{0}\end{cases}
\end{aligned}
$$

Here $M_{j k}^{*}$ is the latent variable for migration decision, and $M_{j k}$ is the observed years of migration duration to the current state $k$ from the time individual $j$ decided to migrate to state $k$ by comparing the costs and benefits using a net benefit function or latent index expressed in equation (1). Similarly, $I_{i k}^{*}$ is the latent job placement and $I_{j k}$ is the dummy of job placement in the formal and informal sectors for the same 
individual $j$ living in state $\mathrm{k}$ which can be seen arising by comparing the job qualifications and job related network information (such as informal or formal referral system) required for the job placement expressed in equation (2). In this setup the first dependent variable, $M_{j k}$, appears in the second equation as an endogenous variable. Here, $X_{j k}$ includes the following set of controls: personal and household characteristics, family background information, family composition information and dependency ratio (the number of children and old aged persons as a proportion of the household size), religion, and a dummy variable indicating whether or not the person is an urban native (the dummy is equal to one if the individual $i$ who currently resides in state $k$ is born in an urban area and zero if the person is a rural-to-urban migrant). Personal characteristics include age, age ${ }^{2}$, sex, education and marital information, whereas household characteristics include wealth status of the household which has been constructed using the principal component analysis of the household non-durable assets ${ }^{10}$. Dependency ratio of the household is also controlled for, which is the number of children and old aged persons as a proportion of household size ${ }^{11}$. Family background information contains variables on father's education and occupation history. $\gamma_{k}^{M}$ and $\gamma_{k}^{I}$ are unmeasured determinants of $M_{i k}$ (e.g., migrant's own community network) and $I_{i k}$ which is fixed at the state level (e.g., state's specialization in a particular occupational sector). $M_{0}$ and $I_{0}$ are unknown thresholds. Finally, $\epsilon_{i k}^{M}$ and $\epsilon_{i k}^{I}$ are non-systematic errors which follow $E\left(\epsilon_{i k}^{M} \mid X_{i k}, Z_{k}, \gamma_{k}^{M}\right)=0$ and $\left(\epsilon_{i k}^{I} \mid X_{i k}, \gamma_{k}^{I}\right)=0$.

Given the setup of binary outcomes with a continuous endogenous variable, we use maximum-likelihood to estimate a multivariate probit model, which we will refer to by following the common practice of mentioning it as a IV-Probit model ${ }^{12}$.

\subsection{Estimation}

As discussed above we estimated a limited-information maximum-likelihood model for the probability of an individual being in the informal sector as a function of the duration of migration (for rural-to-urban migrants), demographic characteristics, household characteristics, religion and family background information, shown in Table 5. In addition we included state, district and city-level fixed effects to capture unobserved geographical and regional impacts on an individual's job placement in the informal sector. Robust standard errors at the individual level are employed for all regressions to derive statistical inference. Column (1)-(4) depict the estimations using historic migration rate based IV whereas Column (5)-(8) used the economic growth based IV to show the consistency of our estimations. For robustness check of our estimations, we used full sample (column 1-2 and column 5-6) as well as male only sub-samples, (column 3-4 and column 7-8). In all regressions, using different sub-samples and different IVs, our results are largely consistent and none of the variables changed sign. We reported the marginal effects of all estimations in columns (2), (4), (6) and (8) respectively. To show consistency in our estimation, we have also estimated a simple probit model without treating the duration of migration as endogenous, shown in column (9). The probit result shows a small and negative but statistically insignificance impact of migration duration on probability of someone being in the informal sector. Once we instrument for migration duration in columns (1)-(8), however, this effect becomes larger and 
Table 5 IV-Probit estimates of the probability for informal sector employment

\begin{tabular}{|c|c|c|c|c|c|c|c|c|c|}
\hline \multirow[b]{3}{*}{$\begin{array}{l}\text { Dependent Variable: } \\
\text { Employment at Informal } \\
\text { sector }\end{array}$} & \multicolumn{4}{|c|}{ IV1: Historical migration rate: state level } & \multicolumn{4}{|c|}{ IV2: Economic growth of 94: State level } & \multirow{3}{*}{$\begin{array}{l}\text { Simple probit } \\
\text { (9) } \\
\text { Coefficient }\end{array}$} \\
\hline & \multicolumn{2}{|c|}{ Full sample } & \multicolumn{2}{|l|}{ Male only } & \multicolumn{2}{|c|}{ Full sample } & \multicolumn{2}{|l|}{ Male only } & \\
\hline & $\begin{array}{l}\text { (1) } \\
\text { Coefficient }\end{array}$ & $\begin{array}{l}\text { (2) } \\
\text { M.E. }\end{array}$ & $\begin{array}{l}\text { (3) } \\
\text { Coefficient }\end{array}$ & $\begin{array}{l}\text { (4) } \\
\text { M.E. }\end{array}$ & $\begin{array}{l}\text { (5) } \\
\text { Coefficient }\end{array}$ & $\begin{array}{l}\text { (6) } \\
\text { M.E. }\end{array}$ & $\begin{array}{l}\overline{\text { (7) }} \\
\text { Coefficient }\end{array}$ & $\begin{array}{l}\text { (8) } \\
\text { M.E. }\end{array}$ & \\
\hline \multirow[t]{2}{*}{ Migration duration } & $-0.073^{* * *}$ & $-0.028^{* * *}$ & $-0.073^{* * *}$ & $-0.028^{* * *}$ & $-0.073^{* * *}$ & $-0.028^{* * *}$ & $-0.073^{* *}$ & $-0.028^{* *}$ & -0.003 \\
\hline & $(0.016)$ & $(0.006)$ & $(0.018)$ & $(0.007)$ & $(0.024)$ & $(0.010)$ & $(0.032)$ & $(0.013)$ & $(0.002)$ \\
\hline \multirow[t]{2}{*}{ Urban Native } & $-0.512^{* * *}$ & $-0.187^{* * *}$ & $-0.517^{* * *}$ & $-0.190^{* * *}$ & $-0.509^{* * *}$ & $-0.186^{* * *}$ & $-0.511^{* * *}$ & $-0.188^{* * *}$ & $-0.130^{* * *}$ \\
\hline & $(0.085)$ & $(0.031)$ & $(0.096)$ & $(0.035)$ & $(0.125)$ & $(0.046)$ & $(0.164)$ & $(0.060)$ & $(0.036)$ \\
\hline \multirow[t]{2}{*}{ No. of Households } & $0.032^{* * *}$ & $0.012^{* * *}$ & $0.033^{* * *}$ & $0.013^{* * *}$ & $0.032^{* * *}$ & $0.012^{* * *}$ & $0.033^{* *}$ & $0.013^{* * *}$ & $0.042^{* * *}$ \\
\hline & $(0.009)$ & $(0.003)$ & $(0.010)$ & $(0.004)$ & $(0.010)$ & $(0.004)$ & $(0.013)$ & $(0.005)$ & $(0.008)$ \\
\hline \multirow[t]{2}{*}{ Married } & 0.108 & 0.041 & 0.081 & 0.031 & 0.104 & 0.040 & 0.079 & 0.030 & 0.047 \\
\hline & $(0.102)$ & $(0.038)$ & $(0.110)$ & $(0.042)$ & $(0.103)$ & $(0.038)$ & $(0.111)$ & $(0.042)$ & $(0.118)$ \\
\hline \multirow[t]{2}{*}{ Primary Education } & $-0.135^{* *}$ & $-0.051^{* *}$ & -0.077 & -0.029 & $-0.134^{* *}$ & $-0.051^{* *}$ & -0.076 & -0.029 & $-0.174^{* * *}$ \\
\hline & $(0.063)$ & $(0.023)$ & $(0.066)$ & $(0.025)$ & $(0.066)$ & $(0.024)$ & $(0.069)$ & $(0.026)$ & $(0.066)$ \\
\hline \multirow[t]{2}{*}{ Secondary Education } & $-0.306^{* * *}$ & $-0.114^{* * *}$ & $-0.268^{* * *}$ & $-0.101^{* * *}$ & $-0.306^{* * *}$ & $-0.115^{* * *}$ & $-0.267^{* * *}$ & $-0.101^{* * *}$ & $-0.364^{* * *}$ \\
\hline & $(0.062)$ & $(0.022)$ & $(0.067)$ & $(0.024)$ & $(0.072)$ & $(0.025)$ & $(0.083)$ & $(0.029)$ & $(0.058)$ \\
\hline \multirow[t]{2}{*}{ Matric Completed } & $-0.562^{* * *}$ & $-0.201^{* * *}$ & $-0.547^{* * *}$ & $-0.198^{* * *}$ & $-0.563^{* * *}$ & $-0.202^{* * *}$ & $-0.549^{* * *}$ & $-0.199^{* * *}$ & $-0.674^{* * *}$ \\
\hline & $(0.081)$ & $(0.024)$ & $(0.086)$ & $(0.027)$ & $(0.107)$ & $(0.031)$ & $(0.125)$ & $(0.037)$ & $(0.061)$ \\
\hline \multirow[t]{2}{*}{ Tertiary Education } & $-0.716^{* * *}$ & $-0.246^{* * *}$ & $-0.700^{* * *}$ & $-0.243^{* * *}$ & $-0.715^{* * *}$ & $-0.246^{* * *}$ & $-0.700^{* * *}$ & $-0.244^{* * *}$ & $-0.880^{* * *}$ \\
\hline & $(0.101)$ & $(0.026)$ & $(0.109)$ & $(0.029)$ & $(0.139)$ & $(0.035)$ & $(0.167)$ & $(0.044)$ & $(0.065)$ \\
\hline \multirow[t]{2}{*}{ Graduate } & $-0.958^{* * *}$ & $-0.335^{* * *}$ & $-0.953^{* * *}$ & $-0.337^{* * *}$ & $-0.956^{* * *}$ & $-0.335^{* * *}$ & $-0.954^{* * *}$ & $-0.337^{* * *}$ & $-1.169^{* * *}$ \\
\hline & $(0.121)$ & $(0.033)$ & $(0.131)$ & $(0.037)$ & $(0.173)$ & $(0.047)$ & $(0.211)$ & $(0.058)$ & $(0.063)$ \\
\hline \multirow[t]{2}{*}{ High caste } & $0.101^{*}$ & $0.039^{*}$ & $0.092^{*}$ & $0.036^{*}$ & $0.102^{*}$ & $0.040^{*}$ & $0.093^{*}$ & $0.036^{*}$ & $0.103^{*}$ \\
\hline & $(0.052)$ & $(0.020)$ & $(0.054)$ & $(0.021)$ & $(0.052)$ & $(0.020)$ & $(0.055)$ & $(0.021)$ & $(0.057)$ \\
\hline \multirow[t]{2}{*}{ OBC } & $0.119^{* *}$ & $0.046^{* *}$ & $0.122^{* *}$ & $0.047^{* *}$ & $0.122^{* *}$ & $0.047^{* *}$ & $0.125^{*}$ & $0.049^{*}$ & $0.182^{* * *}$ \\
\hline & $(0.056)$ & $(0.022)$ & $(0.058)$ & $(0.023)$ & $(0.062)$ & $(0.024)$ & $(0.067)$ & $(0.026)$ & $(0.057)$ \\
\hline
\end{tabular}


Table 5 IV-Probit estimates of the probability for informal sector employment (Continued)

\begin{tabular}{|c|c|c|c|c|c|c|c|c|c|}
\hline \multirow[t]{2}{*}{$\overline{\text { Dalit }}$} & 0.015 & 0.006 & -0.009 & -0.004 & 0.019 & 0.008 & -0.005 & -0.002 & 0.022 \\
\hline & $(0.056)$ & $(0.022)$ & $(0.059)$ & $(0.023)$ & $(0.056)$ & $(0.022)$ & $(0.059)$ & $(0.023)$ & $(0.062)$ \\
\hline \multirow[t]{2}{*}{ Adivasi } & $-0.185^{* *}$ & $-0.069^{* *}$ & $-0.180^{*}$ & $-0.068^{* *}$ & $-0.181^{* *}$ & $-0.068^{* *}$ & $-0.177^{*}$ & $-0.067^{*}$ & $-0.195^{* *}$ \\
\hline & $(0.090)$ & $(0.033)$ & $(0.095)$ & $(0.035)$ & $(0.091)$ & $(0.033)$ & $(0.097)$ & $(0.035)$ & $(0.098)$ \\
\hline \multirow[t]{2}{*}{ Muslim } & $0.171^{* *}$ & $0.067^{* *}$ & $0.191 * *$ & $0.075^{* *}$ & $0.175^{* *}$ & $0.068^{* *}$ & $0.195^{*}$ & $0.077^{* *}$ & $0.297^{* * *}$ \\
\hline & $(0.073)$ & $(0.028)$ & $(0.076)$ & $(0.030)$ & $(0.088)$ & $(0.034)$ & $(0.100)$ & $(0.039)$ & $(0.065)$ \\
\hline \multirow[t]{2}{*}{ Sikh, Jain } & 0.086 & 0.033 & 0.049 & 0.019 & 0.088 & 0.034 & 0.051 & 0.020 & 0.168 \\
\hline & $(0.100)$ & (0.039) & (0.104) & $(0.041)$ & $(0.105)$ & $(0.041)$ & $(0.115)$ & $(0.045)$ & $(0.105)$ \\
\hline \multirow[t]{2}{*}{ Christian } & -0.055 & -0.021 & -0.074 & -0.028 & -0.053 & -0.020 & -0.072 & -0.028 & -0.106 \\
\hline & $(0.112)$ & $(0.043)$ & (0.119) & $(0.045)$ & $(0.114)$ & $(0.043)$ & $(0.120)$ & $(0.046)$ & $(0.120)$ \\
\hline \multirow[t]{2}{*}{ Dependency Ratio } & $-0.120^{*}$ & $-0.046^{*}$ & $-0.121^{*}$ & $-0.047^{*}$ & $-0.117^{*}$ & $-0.045^{*}$ & -0.116 & -0.045 & -0.104 \\
\hline & $(0.067)$ & $(0.026)$ & $(0.071)$ & $(0.028)$ & $(0.067)$ & $(0.026)$ & $(0.072)$ & $(0.028)$ & $(0.073)$ \\
\hline City Dummies & Yes & Yes & Yes & Yes & Yes & Yes & Yes & Yes & Yes \\
\hline District Dummies & Yes & Yes & Yes & Yes & Yes & Yes & Yes & Yes & Yes \\
\hline State Dummies & Yes & Yes & Yes & Yes & Yes & Yes & Yes & Yes & Yes \\
\hline Observations & 10,521 & 10,521 & 9,668 & 9,668 & 10,485 & 10,485 & 9,641 & 9,641 & 10521 \\
\hline Log pseudolikelihood & -42610 & -42610 & -38930 & -38930 & -42490 & -42490 & -38842 & -38842 & -5704 \\
\hline chi2 & 133216 & 133216 & 12254 & 12254 & 3407 & 3407 & 3169 & 3169 & 2259 \\
\hline F-Statistics at First Stage & 26.91 & & 25.44 & & 26.83 & & 37.69 & & . \\
\hline Wald test of exogeneity & $14.66^{* * *}$ & $14.66^{* * *}$ & $13.31^{* * *}$ & $13.31^{* * *}$ & $4.814^{* *}$ & $4.814^{* *}$ & $2.805^{* *}$ & $2.805^{* *}$ & . \\
\hline
\end{tabular}

Source: Indian Human Development Survey 2005: Authors own Calculations. Notes: Robust standard errors in parentheses. Significance code: ${ }^{*} p<0.1,{ }^{* *} p<0.05$, ${ }^{* * *} p<0.01$. M.E. Stands for Marginal Effects which have been calculated at the mean. In all these specifications, we are considering only those as migrant who have migrated from rural to urban areas for jobs. Those who were born in urban setup and migrated to another urban area for job are not considered as migrants.

In the regression we also control for head of the households age, age squared, sex, asset status and fathers education and occupation. 
statistically more significant. This result implies that the longer the migrant is staying in the urban areas, the more likely s/he is to find an employment in the formal sector, as the person could acquire experience, networks and skill-sets which could be instrumental in getting a job in the formal sector. Given the fact that some migrants have already returned back after realizing their negligible probability of securing a formal employment in the urban areas, those who remained in the urban areas, prefer formal employment more than the non-migrants and our results show that each additional year of migration time-length increases the probability of being in the formal sector significantly.

We would expect the higher the education of an individual, the lower the probability of belonging to the informal sector. Our estimations, see Table 5, show clearly that the higher the level of education of the household head the lower the probability of being in the informal sector, and the coefficients get smaller (bigger in absolute value) respectively. The results for father's education are very similar to the household head's education level. Further, we would expect that if the father of the individual was of a higher social class (in terms of occupation), the probability of being in the informal sector would be lower. Again the evidence supports the view that the parent's occupation clearly influences an individual's employment placement: if the father's occupation is formal in nature like executive or clerk, the probability of being in the informal sector is lower, while if the father's occupation is sales (which is mostly informal in nature in the Indian context), then there is a higher probability of being in the informal sector. As discussed earlier, we would expect a person from a socially disadvantaged caste or religion more likely to be in the informal sector. Our findings show that $\mathrm{OBC}$ (Other Backward Classes) and Muslims are more likely to be in the informal sector. We did not find any statistically significance for Dalits (the lower social castes) in the informal sector compared with Brahmins, which may be attributable to the government's positive discrimination in employment in the government sector (reservation system) for Dalits. As we would expect, the wealthier the household head, the less likely s/he would be in the informal sector. We found that dependency ration is weakly significant and the sign is negative, suggests that a higher dependency ratio would lead the person transition out of the informal sector into the formal sector as the person would be willing to accept any formal sector job offer which enables better security, however, such an issue appears to be not very influential in explaining the probability of being in the informal sector.

Our results suggest that urban natives are more likely to be in the formal sector as they have more access to better schools, social networks and job information and referrals compared with the rural-to-urban migrants. Our main variable of interest is rural migration duration. In all cases it is negative and significant at the $1 \%$ level. In other words, the longer a rural migrant has been in an urban area the more likely that individual would have moved to the formal sector. (Note the rural migration duration variable has been instrumented).

The validity of IV estimations depends on the power of instruments in explaining the predicted values at the first stage. As reported, all the first stage regressions have very high F-statistics (for example, for our preferred specification of column 
1, the first stage F-statistic is 26.91). We have also tested for the joint significance of our IVs, and the results overwhelmingly reject the null of no joint significance. The Wald statistic of the exogeneity test has rejected the null hypothesis of no endogeneity. We have also tested the instruments using the typical 2SLS models to test for the over-identification test (Anderson canonical correlations test) and under-identification test (Sargan-Hansen test) which have duly supported our instruments.

\subsection{Multinomial estimation (Formal, self-employed and Informal wage)}

In this section we have separated the informal sector into those who are self-employed and those who work in the informal or formal sectors as wage labourers to check whether or not highly qualified individuals are employed in the formal sector and also to check if migrants use the informal sector as their temporary base. We did this check by employing a multinomial logit job attainment model following the work of Xin Meng (2001).

\subsection{Econometric modelling}

Standard neo-classical economic rationality for an individual's job placement (labour supply) is a function of individual endowments and human resources (e.g., level of education and experience). However, other related factors that could also have an impact on an individual's labour supply, especially in the context of India, could be the family size (Brown et al. 1980), family background, caste and religious affiliation (see for example Banerjee and Knight (1985) or Ito (2009)). Another less frequently studied factor that might be critical is the job related network, for example, job-opening information, formal and informal channels of job search and referral (see for example Holzer 1987 or Calvó-Armengol and Zenou (2005)). Since urban natives usually have a better endowment of job-related networks and referrals, we could hypothesise that migrants will acquire access to such networks as their migration duration increases and hence are less likely to be in informal wage labour.

A multinomial logit model is specified below to capture how these variables will influence an individual $j$ 's probability of working in sector $s$. Formally the model is:

$$
P_{j s}=\operatorname{prob}\left(y_{j}=\text { sector }_{s}\right)=\frac{e^{x_{j}^{\prime} \beta_{s}}}{\sum_{s=1}^{S} e^{x_{j}^{\prime} \beta_{l}}} j=1, \ldots \ldots, N ; s=1, \ldots \ldots, S
$$

where $N$ is the size of the sample, $S$ is the number of sectors and $x_{j}$ is a vector of variables affecting the labour placement outcome $y_{j}$. The dependent variable $y_{j}$ for equation (3) is the nature of an individual's current job in any of the three sectors: formal sector, self-employment or informal wage labour sector. Our main variable of interest, years of migration duration, is endogenous in nature. Hence to allow for the endogeneity in estimating equation (3), we first used the fitted value of migration duration using all the instruments (estimation done through OLS). In the second step we used the fitted value of the migration duration in equation 3. The standard errors of the estimates in the second step have been estimated through a bootstrapping process with 100 replications. 


\subsection{Estimations}

The results of marginal effects of endogenous multinomial probit estimations are reported in Table 6 with full sample and in Table 7 with male only sub-sample. The dependent variable has been categorized into three groups with formal sector employment being used as a base category. Column (1)-(3) report the estimations using the historic migration rate as an IV whereas column (4)-(6) are estimated employing state-level economic growth of 1994 as IV.

Tables 6 and 7 are broadly similar to those reported in Section 5 of the IV-probit model (Table 5). For both the self-employed and informal wage labour sectors, education, father's characteristics, and the caste and religion coefficients have essentially the same signs and significance. The main point of difference is that a rural migrant's duration of migration does not significantly influence the probability of being in the self-employed sector, but is negative and significant for the informal wage labour sector and positive and significant for formal employment. In other words, we find that the longer a rural migrant has been in the urban sector the less likely he would be in informal wage employment and more likely to be in the formal sector. For instance, an individual with one additional year's of migration duration from the rural area reduces his/ her probability to be in informal wage employment by $2.9 \%$ and increases the probability of being in the formal employment by about $3 \%$. However, this variable has no statistically discernible effect on him/her being in the self-employed sectors. Results on education are consistent with the other findings that with more years of education, individuals will less likely be in the informal sector and more likely to be in the formal sector. In the case of self-employment, education up to the tertiary level does not have any statistically significant impact; however, for above tertiary level education, the probability of someone being in self-employed sector is significantly reduced.

The validity of multinomial regression lies on the strong assumption of the Independence of Irrelevant Alternatives (IIA), which means that adding or deleting alternative outcome categories does not affect the odds among the remaining outcomes. To check whether this assumption holds in our case, we have performed the test for the IIA assumption, and we find no evidence violating the assumption (using the full-sample specification of Table 6).

\section{Conclusions}

In our paper we have defined migrants as those individuals who have migrated from rural to urban areas. Those who were born in urban areas and migrated to another urban area are not considered as migrants ${ }^{13}$. Also note that in our multinomial logit regressions, for the sake of simplicity of estimation, we used only the rural-to-urban migration duration as endogenous and properly took care of such endogenous regression by using instruments to predict the fitted value of the variable and plugged in the fitted value in the final multinomial regression. One could argue, however, that urbanto-urban migration could also be endogenous. We have also used urban-to-urban migration as endogenous in separate regression estimations in the multinomial logit framework (not reported) and in a linear probability model, and in both cases the variable was insignificant and did not appear to be influential in explaining the likelihood of person's placement in the informal labour market. 
Table 6 Marginal effects of multinomial logit regression (full sample)

\begin{tabular}{|c|c|c|c|c|c|c|}
\hline \multirow[b]{4}{*}{ Variables } & \multirow{2}{*}{\multicolumn{3}{|c|}{$\begin{array}{l}\text { IV1: Historic migration rate: } \\
\text { state level } \\
\text { Full sample } \\
\end{array}$}} & \multirow{2}{*}{\multicolumn{3}{|c|}{$\begin{array}{l}\text { IV2: Economic growth of } 94: \\
\text { state level } \\
\text { Full sample }\end{array}$}} \\
\hline & & & & & & \\
\hline & $(1)$ & (2) & (3) & (4) & (5) & (6) \\
\hline & Formal & $\begin{array}{l}\text { Self } \\
\text { employment }\end{array}$ & $\begin{array}{l}\text { Informal } \\
\text { wage labour }\end{array}$ & Formal & $\begin{array}{l}\text { Self } \\
\text { employment }\end{array}$ & $\begin{array}{l}\text { Informal } \\
\text { wage labour }\end{array}$ \\
\hline \multirow[t]{2}{*}{ Migration Duration } & $0.0305^{* * *}$ & -0.00154 & $-0.0290^{* * *}$ & $0.0255^{* *}$ & -0.00428 & $-0.0212^{* *}$ \\
\hline & $(0.00993)$ & $(0.00719)$ & $(0.00877)$ & $(0.0124)$ & $(0.00804)$ & $(0.00962)$ \\
\hline \multirow[t]{2}{*}{ Urban Native } & $0.190^{* * *}$ & -0.0206 & $-0.169^{* * *}$ & $0.170^{* * *}$ & -0.0328 & $-0.137^{* * *}$ \\
\hline & $(0.0470)$ & $(0.0371)$ & $(0.0364)$ & $(0.0600)$ & $(0.0400)$ & $(0.0420)$ \\
\hline \multirow[t]{2}{*}{ No. of Households } & $-0.0150^{* * *}$ & 0.00247 & $0.0126^{* * *}$ & $-0.0152^{* * *}$ & $0.00240^{*}$ & $0.0128^{* * *}$ \\
\hline & $(0.00302)$ & $(0.00175)$ & $(0.00255)$ & $(0.00312)$ & $(0.00140)$ & $(0.00277)$ \\
\hline \multirow[t]{2}{*}{ Married } & -0.0322 & -0.0219 & $0.0541^{*}$ & -0.0267 & -0.0196 & 0.0463 \\
\hline & $(0.0427)$ & $(0.0305)$ & $(0.0320)$ & $(0.0527)$ & $(0.0340)$ & $(0.0388)$ \\
\hline \multirow[t]{2}{*}{ Primary Education } & 0.0319 & 0.0308 & $-0.0627^{* * *}$ & 0.0323 & 0.0310 & $-0.0633^{* * *}$ \\
\hline & $(0.0266)$ & (0.0209) & $(0.0164)$ & $(0.0273)$ & $(0.0202)$ & $(0.0155)$ \\
\hline \multirow[t]{2}{*}{ Secondary Education } & $0.0972^{* * *}$ & 0.0208 & $-0.118^{* * *}$ & $0.0971^{* * *}$ & 0.0200 & $-0.117^{* * *}$ \\
\hline & $(0.0213)$ & $(0.0167)$ & $(0.0137)$ & $(0.0191)$ & $(0.0144)$ & $(0.0125)$ \\
\hline \multirow[t]{2}{*}{ Matric Completed } & $0.181^{* * *}$ & -0.00272 & $-0.178^{* * *}$ & $0.181^{* * *}$ & -0.00319 & $-0.178^{* * *}$ \\
\hline & $(0.0193)$ & $(0.0151)$ & $(0.0124)$ & $(0.0184)$ & $(0.0137)$ & $(0.0114)$ \\
\hline \multirow[t]{2}{*}{ Tertiary Education } & $0.220^{* * *}$ & -0.0139 & $-0.206^{* * *}$ & $0.220^{* * *}$ & -0.0138 & $-0.206^{* * *}$ \\
\hline & $(0.0197)$ & $(0.0162)$ & $(0.0108)$ & $(0.0176)$ & $(0.0138)$ & (0.00948) \\
\hline \multirow[t]{2}{*}{ Graduate } & $0.339^{* * *}$ & $-0.0454^{* * *}$ & $-0.293^{* * *}$ & $0.339^{* * *}$ & $-0.0457^{* * *}$ & $-0.293^{* * *}$ \\
\hline & $(0.0192)$ & $(0.0134)$ & $(0.0151)$ & $(0.0166)$ & $(0.0116)$ & $(0.0132)$ \\
\hline \multirow[t]{2}{*}{ High caste } & $-0.0474^{*}$ & 0.0254 & 0.0220 & $-0.0463^{*}$ & $0.0265^{*}$ & 0.0198 \\
\hline & $(0.0256)$ & $(0.0169)$ & $(0.0215)$ & $(0.0260)$ & $(0.0145)$ & $(0.0248)$ \\
\hline \multirow[t]{2}{*}{ OBC } & $-0.0659 * * *$ & $0.0290^{* *}$ & $0.0369^{* *}$ & $-0.0685^{* * *}$ & $0.0283^{*}$ & $0.0403^{*}$ \\
\hline & $(0.0208)$ & $(0.0145)$ & $(0.0178)$ & $(0.0244)$ & $(0.0158)$ & $(0.0211)$ \\
\hline \multirow[t]{2}{*}{ Dalit } & -0.00897 & $-0.0369^{* * *}$ & $0.0458^{* *}$ & -0.0104 & $-0.0371^{* * *}$ & $0.0475^{* *}$ \\
\hline & $(0.0233)$ & $(0.0123)$ & $(0.0207)$ & $(0.0237)$ & $(0.0118)$ & $(0.0219)$ \\
\hline \multirow[t]{2}{*}{ Adivasi } & $0.0664^{*}$ & -0.0315 & -0.0348 & $0.0635^{*}$ & $-0.0321^{*}$ & -0.0315 \\
\hline & $(0.0339)$ & (0.0193) & $(0.0277)$ & $(0.0360)$ & $(0.0186)$ & $(0.0340)$ \\
\hline \multirow[t]{2}{*}{ Muslim } & $-0.0945^{* * *}$ & 0.0305 & $0.0640^{* * *}$ & $-0.101^{* * *}$ & 0.0277 & $0.0732^{* * *}$ \\
\hline & $(0.0282)$ & $(0.0190)$ & $(0.0231)$ & $(0.0288)$ & $(0.0214)$ & $(0.0273)$ \\
\hline \multirow[t]{2}{*}{ Sikh, Jain } & -0.0391 & 0.0342 & 0.00493 & -0.0425 & 0.0321 & 0.0105 \\
\hline & $(0.0464)$ & $(0.0307)$ & $(0.0473)$ & $(0.0463)$ & $(0.0317)$ & $(0.0467)$ \\
\hline \multirow[t]{2}{*}{ Christian } & 0.0301 & $-0.0680^{* * *}$ & 0.0379 & 0.0334 & $-0.0674^{* * *}$ & 0.0340 \\
\hline & $(0.0479)$ & $(0.0234)$ & $(0.0457)$ & $(0.0441)$ & $(0.0194)$ & $(0.0417)$ \\
\hline \multirow[t]{2}{*}{ Dependency Ratio } & $0.0524^{*}$ & -0.0244 & -0.0279 & $0.0485^{*}$ & $-0.0262^{*}$ & -0.0223 \\
\hline & $(0.0286)$ & $(0.0158)$ & $(0.0244)$ & $(0.0291)$ & $(0.0153)$ & $(0.0222)$ \\
\hline Observations & 10,521 & 10,521 & 10,521 & 10,485 & 10,485 & 10,485 \\
\hline
\end{tabular}

Source: Indian Human Development Survey 2005: Authors own Calculations. Notes: Robust standard errors in parentheses. The standard errors of the estimates in the second step have been estimated through a bootstrapping process with 100 replications. Significance code: ${ }^{*} \mathrm{p}<0.1,{ }^{* *} \mathrm{p}<0.05,{ }^{* * *} \mathrm{p}<0.01$. In all these specifications, we are considering only those as migrant who have migrated from rural to urban areas for jobs. Those who were born in urban setup and migrated to another urban area for job are not considered as migrants.

In the regression we also control for head of the households age, age squared, sex, asset status and fathers education and occupation. All regressions controlled for district, state and city fixed effects as well. 
Table 7 Marginal effects of multinomial logit regression (male only sample)

\begin{tabular}{|c|c|c|c|c|c|c|}
\hline \multirow[b]{4}{*}{ Variables } & \multirow{2}{*}{\multicolumn{3}{|c|}{$\begin{array}{l}\text { IV1: Historic migration rate: } \\
\text { state level } \\
\text { Full sample }\end{array}$}} & \multirow{2}{*}{\multicolumn{3}{|c|}{$\begin{array}{l}\text { IV2: Economic growth of 94: } \\
\text { state level } \\
\text { Full sample }\end{array}$}} \\
\hline & & & & & & \\
\hline & (1) & (2) & (3) & (4) & $(5)$ & (6) \\
\hline & Formal & $\begin{array}{l}\text { Self- } \\
\text { employment }\end{array}$ & $\begin{array}{l}\text { Informal } \\
\text { wage labour }\end{array}$ & Formal & $\begin{array}{l}\text { Self- } \\
\text { employment }\end{array}$ & $\begin{array}{l}\text { Informal } \\
\text { wage labour }\end{array}$ \\
\hline \multirow[t]{2}{*}{ Migration Duration } & $0.0306^{* *}$ & 0.00113 & $-0.0317^{* * *}$ & $0.0235^{*}$ & -0.00190 & $-0.0216^{* *}$ \\
\hline & $(0.0119)$ & $(0.00805)$ & $(0.00925)$ & $(0.0138)$ & $(0.00845)$ & $(0.0105)$ \\
\hline \multirow[t]{2}{*}{ Urban Native } & $0.190^{* * *}$ & -0.00916 & $-0.181^{* * *}$ & $0.163^{* *}$ & -0.0229 & $-0.140^{* * *}$ \\
\hline & $(0.0574)$ & $(0.0437)$ & $(0.0359)$ & $(0.0675)$ & $(0.0440)$ & $(0.0460)$ \\
\hline \multirow[t]{2}{*}{ No. of Households } & $-0.0162^{* * *}$ & 0.00251 & $0.0137^{* * *}$ & $-0.0166^{* * *}$ & 0.00235 & $0.0143^{* * *}$ \\
\hline & $(0.00335)$ & $(0.00180)$ & $(0.00272)$ & $(0.00366)$ & $(0.00196)$ & $(0.00307)$ \\
\hline \multirow[t]{2}{*}{ Married } & -0.0223 & -0.0238 & 0.0462 & -0.0171 & -0.0226 & 0.0396 \\
\hline & $(0.0448)$ & $(0.0351)$ & $(0.0340)$ & $(0.0559)$ & $(0.0403)$ & $(0.0393)$ \\
\hline \multirow[t]{2}{*}{ Primary Education } & 0.00532 & $0.0435^{* *}$ & $-0.0488^{* * *}$ & 0.00467 & $0.0450^{*}$ & $-0.0497^{* * *}$ \\
\hline & $(0.0272)$ & $(0.0219)$ & $(0.0153)$ & $(0.0328)$ & $(0.0251)$ & $(0.0186)$ \\
\hline \multirow[t]{2}{*}{ Secondary Education } & $0.0827^{* * *}$ & 0.0257 & $-0.108^{* * *}$ & $0.0815^{* * *}$ & 0.0266 & $-0.108^{* * *}$ \\
\hline & $(0.0241)$ & $(0.0181)$ & $(0.0152)$ & $(0.0262)$ & $(0.0190)$ & $(0.0158)$ \\
\hline \multirow[t]{2}{*}{ Matric Completed } & $0.178^{* * *}$ & -0.000493 & $-0.177^{* * *}$ & $0.177^{* * *}$ & -0.000998 & $-0.176^{* * *}$ \\
\hline & $(0.0219)$ & $(0.0169)$ & $(0.0129)$ & $(0.0247)$ & (0) & $(0.0143)$ \\
\hline \multirow[t]{2}{*}{ Tertiary Education } & $0.217^{* * *}$ & -0.0108 & $-0.206^{* * *}$ & $0.216^{* * *}$ & -0.0109 & $-0.205^{* * *}$ \\
\hline & $(0.0196)$ & $(0.0163)$ & $(0.0121)$ & $(0.0231)$ & (0.0193) & $(0.0130)$ \\
\hline \multirow[t]{2}{*}{ Graduate } & $0.339^{* * *}$ & $-0.0422^{* * *}$ & $-0.297^{* * *}$ & $0.339^{* * *}$ & $-0.0438^{* * *}$ & $-0.295^{* * *}$ \\
\hline & $(0.0208)$ & $(0.0141)$ & $(0.0159)$ & $(0.0231)$ & $(0.0164)$ & $(0.0160)$ \\
\hline \multirow[t]{2}{*}{ High caste } & $-0.0423^{*}$ & $0.0254^{*}$ & 0.0170 & -0.0407 & 0.0272 & 0.0136 \\
\hline & $(0.0232)$ & $(0.0147)$ & $(0.0215)$ & $(0.0250)$ & $(0.0167)$ & $(0.0249)$ \\
\hline \multirow[t]{2}{*}{ OBC } & $-0.0658^{* * *}$ & $0.0315^{* *}$ & 0.0342 & $-0.0685^{* *}$ & $0.0315^{* *}$ & 0.0370 \\
\hline & $(0.0208)$ & $(0.0157)$ & $(0.0217)$ & $(0.0288)$ & $(0.0151)$ & $(0.0250)$ \\
\hline \multirow[t]{2}{*}{ Dalit } & 0.00337 & $-0.0401^{* * *}$ & 0.0367 & 0.00249 & $-0.0422^{* * *}$ & 0.0397 \\
\hline & $(0.0255)$ & $(0.0122)$ & $(0.0242)$ & $(0.0271)$ & $(0.0139)$ & $(0.0271)$ \\
\hline \multirow[t]{2}{*}{ Adivasi } & $0.0668^{*}$ & -0.0257 & -0.0411 & 0.0646 & -0.0273 & -0.0373 \\
\hline & $(0.0374)$ & $(0.0216)$ & $(0.0305)$ & $(0.0447)$ & $(0.0228)$ & $(0.0372)$ \\
\hline \multirow[t]{2}{*}{ Muslim } & $-0.104^{* * *}$ & 0.0362 & $0.0674^{* *}$ & $-0.110^{* * *}$ & $0.0344^{*}$ & $0.0761^{* *}$ \\
\hline & $(0.0326)$ & $(0.0227)$ & $(0.0307)$ & $(0.0331)$ & $(0.0204)$ & $(0.0316)$ \\
\hline \multirow[t]{2}{*}{ Sikh, Jain } & -0.0211 & 0.0373 & -0.0162 & -0.0273 & 0.0350 & -0.00766 \\
\hline & $(0.0409)$ & $(0.0308)$ & $(0.0435)$ & $(0.0473)$ & $(0.0292)$ & $(0.0437)$ \\
\hline \multirow[t]{2}{*}{ Christian } & 0.0387 & -0.0723 & 0.0336 & 0.0413 & -0.0747 & 0.0335 \\
\hline & (0.0923) & $(0.116)$ & $(0.0557)$ & $(0.0729)$ & $(0.0766)$ & $(0.0534)$ \\
\hline \multirow[t]{2}{*}{ Dependency Ratio } & $0.0526^{* *}$ & -0.0272 & -0.0254 & $0.0482^{*}$ & $-0.0292^{*}$ & -0.0189 \\
\hline & $(0.0259)$ & $(0.0171)$ & $(0.0244)$ & $(0.0280)$ & $(0.0156)$ & $(0.0243)$ \\
\hline Observations & 9,668 & 9,668 & 9,668 & 9,641 & 9,641 & 9,641 \\
\hline
\end{tabular}

Source: Indian Human Development Survey 2005: Authors own Calculations.

Notes: Robust standard errors in parentheses. The standard errors of the estimates in the second step have been estimated through a bootstrapping process with 100 replications. Significance code: ${ }^{*} p<0.1,{ }^{* *} p<0.05,{ }^{* * *} p<0.01$. In all these specifications, we are considering only those as migrant who have migrated from rural to urban areas for jobs. Those who were born in urban setup and migrated to another urban area for job are not considered as migrants. In the regression we also control for head of the households age, age squared, sex, asset status and fathers education and occupation. All regressions controlled for district, state and city fixed effects as well. 
We argued that Indian urban sector appears to have segmented labour markets: people who are from the lower social classes (castes or religions) are more likely to work in the informal sector. We found that getting more education is one way of getting a job in the formal sector, but perhaps more important are family networks in providing an entry into the formal labour market. We argued that when rural migrants move to the urban sector, they initially find themselves working in the informal sector where they have low incomes and mostly employed in industries like construction, manufacturing, wholesale and retail trades, restaurants and hotels, transport, and social and personal services. Their occupations are mainly in the lower social grades, such as production and related work, transport, sales and service work, and working as labourers. We noted that caste and religion play important roles for the employment and job placement as we see that Brahmins and high caste people are more likely to be in higher level occupations, whereas Dalits and Muslims is mostly employed in nonagricultural day-labour or as artisans.

We argued that there is a hierarchy of preferences that people would prefer to work in the formal sector, with the self-employed sector being the second choice, and lastly working in the informal wage labour market. However, entry into the formal sector is constrained by education, social class, and family ties. Self-employment is constrained by access to the credit market.

We estimated a model of the probability of working in the informal sector as a function of demographic characteristics, education, father's education and occupation, caste and religion, and duration of a migrant in his/her present occupation. We distinguished between migrants who had come from rural areas from those who had moved from other urban areas. We treated the duration of the migrant as an endogenous variable and estimated a two-stage least-squares model. We found that most of the explanatory variables were significant and of the expected signs. In particular, we found that individual's own education as well as father's education and occupational status play significant role in the job placement equation. We also found that Muslims and Other Backward Classes were more likely to be working in the informal sector.

The most interesting finding of our research is that the length of time a rural migrant spends in the urban sector, the more likely s/he moves out of the informal wage sector. In other words, the duration of migration from rural areas is inversely related to the probability of working in the informal sector. This result implies that the longer the migrant is staying in the urban areas, the more likely s/he is to find an employment in the formal sector, as the person could capitalize on his acquired experience, networks and skill-sets due to the migration. Since formal employment provides job security, insurance and other facilities, getting a placement in the formal sector appears to be more preferred option for migrants compared with non-migrants. If a migrant realizes that the probability of finding a formal job is really limited, then the person is more likely to return back to the origin quite early, after comparing the cost and benefits of holding back in the migration destination. As a result, those who remained in the urban area, we find that each additional year of migration duration increases the probability of being in the formal sector for migrants by about $3 \%$. Hence, the longer the duration in the urban sector the less likely is the migrant to be in the informal sector. The results support the view that for migrants, the informal wage labour market may be a stepping stone to a secured life in the formal sector. 
However, using a cross-sectional data set to analyse migration and urban employment is a challenging task. Migrants have a higher attrition probability due to the mobility of the population. Hence, when a researcher is confronted with a migrant population, it is difficult to define the population at hand, as there are constant inflows and outflows of individuals with different traits. Moreover, duration raises the possibility of right censoring which could not be addressed with the data at hand. These results need to be researched further using panel data, which unfortunately are not available as yet.

\section{Endnotes}

${ }^{1}$ For a detailed discussion about the concept and measurement of informality, see Perry et al. (2007). Also see Guha-Khasnobis et al. (2006).

${ }^{2}$ Schneider et al. (2010) provide estimates of the size of "shadow economies" for a range of countries. For India their estimate is an average of $22 \%$ for the period 1999 2006. This is based on macroeconomic estimates for a group of countries using the MIMIC method. However, their estimates rely on only 27 (or 20) degrees of freedom. As our research is primarily about the informal labour market we do not wish to enter into debates about different estimates of the share of the shadow (informal) economy in GDP.

${ }^{3}$ A "good" school would almost certainly be an established private school.

${ }^{4}$ It has been suggested by McMillan and Rodrik (McMillan and Rodrik 2011) that in Latin America the rationalisation of some firms led to lower employment in the formal sector with the redundant workers moving to the lower productivity informal sector, hence average productivity fell.

${ }^{5}$ Of course, some people may prefer informal sector activities, see Perry et al. (2007).

6"Indeed most of the informal salaried appear to be queing for more desirable jobs in either the formal salaried sector or as self-employed workers...", p. 6, Perry et al. (2007).

${ }^{7}$ Perry et al. (2007) has detailed information about Latin America. Alice Sindzingre (in Guha-Khasnobis et al. (2006) also points out that there is a huge variation in earnings and that informal business enterprises heads may have higher earnings than the average wage in the formal sector.

${ }^{8}$ We thank an anonymous referee for suggesting this alternative instrument.

${ }^{9}$ This variable ranks the value of non-durable assets from 1 to 6 Rank 1 , the lowest, is households with a total value of non-durables of less than 500 rupees. Rank 6, the highest, is households with asset valued at more than 20,000 rupees. (On 12th March 2013 the exchange rate was: $100 \mathrm{INR}=1.84$ USD.

${ }^{10}$ We thank an anonymous referee for suggesting this important control variable.

${ }^{11}$ Estimations were carried out by using the IVProbit command with MLE option in STATA version 13.

${ }^{12}$ Those who were born in other countries are not part of the sample in our estimations. 


\section{Acknowledgements}

We are grateful for the data provided by Desai, Sonalde, Reeve Vanneman, and the National Council of Applied Economic Research, New Delhi, India. We also use data from the India Human Development Survey (IHDS), 2005 [Computer File]. ICSPSR22626-v7. Ann Arbor, MI: Inter-university Consortium for Political and Social Research [distributor], 2010-03-25. Doi: 10.3886/ICPSR22626.

An earlier version of this paper was presented to the Arndt-Corden School, ANU and we thank the participants (in particular, Raghav Jha, Peter Warr, and Robert Sparrow) for their helpful comments. A revised version was presented at the Workshop on Emerging Economies held at the University of New South Wales, 2012. We are grateful to our discussant Shiko Maruyama for constructive comments, and to the participants at the workshop for their helpful comments. A special thanks goes to Gary Fields for his useful comments to improve this paper. Authors would also like to convey their gratitude to IDE-JETRO and IZA for allowing this paper to be circulated under respective organization's working paper series. The usual disclaimer applies. Finally, we thank an anonymous referee for making several suggestions that have improved the paper.

Responsible editor: Hartmut Lehmann

\section{Author details}

${ }^{1}$ University of New South Wales, University of Western Sydney, and IZA, Bonn, Germany. ${ }^{2}$ Institute of Developing Economies - Japan External Trade Organization (IDE-JETRO) and University of Tokyo, Tokyo, Japan.

\section{Received: 5 November 2013 Accepted: 22 April 2014}

Published: 09 Jul 2014

\section{References}

Amemiya T (1978) The estimation of a simultaneous equation generalized probit model. Econometrica 46:1193-1205 Banerjee B, Knight JB (1985) Caste discrimination in the Indian urban labour market. J Dev Econ 17(3):277-307 Bromley R (1978) Introduction-The Urban Informal Sector: Why Is It Worth Discussing?". World Dev 6(9/10):1033-1039 Brown RS, Moon M, Zoloth BS (1980) Incorporating occupational attainment in studies of male/female earnings differentials. J Hum Resour 15:3-28

Calvó-Armengol A, Zenou Y (2005) Job matching, social network and word-of-mouth communication. J Urban Econ 57(3):500-522

De Mel S, McKenzie D, Woodruff C (2010) Who are the Microenterprise Owners? Evidence from Sri Lanka on Tokman versus De Soto. In: International Differences in Entrepreneurship. University of Chicago Press, pp 63-87

Fields GS (2009) "Segmented Labor Market Models in Developing Countries." The Oxford handbook of philosophy of economics., pp 476-510

Gerxhani K (2004) The informal sector in developed and less developed countries: A literature survey". Public Choice 120:267-300

Guha-Khasnobis B, Kanbur R, Ostrom E (2006) Linking the Formal and Informal Economy: Concepts and Policies. Oxford Scholarship Online

Hanson GH, Woodruff C (2003) Emigration and educational attainment in Mexico. University of California at San Diego, Mimeo

Hart K (1973) "Informal Income Opportunities and Urban Employment in Ghana'. J Modern Afr Stud 11(1):61-89

Hildebrandt N, McKenzie DJ (2005) The effects of migration on child health in Mexico. Economia 6(1):257-289

Holzer HJ (1987) Informal job search and black youth unemployment. Am Econ Rev 77(3):446-452

International Labour Organisation (1972) Employment, Incomes and Equality: A Strategy for Increasing Productive Employment in Kenya. ILO, Geneva

International Labour Organisation (2002) Decent Work and the Informal Economy. International Labour Conference, Employment, Incomes and Equality: A Strategy for Increasing Productive Employment in Kenya, Geneva

Inter-university Consortium for Political and Social Research (2005) India Human Development Survey (IHDS) 2005. Ann Arbor, Michigan, USA

Ito T (2009) Caste discrimination and transaction costs in the labor market: Evidence from rural North India. J Dev Econ 88(2):292-300

López-Córdoba E (2005) Globalization, migration, and development: the role of Mexican migrant remittances. Economia 6(1):217-256

Mazumdar D (1976) The Urban Informal Sector". World Dev 4(8):655-679

McKenzie DJ, Rapoport H (2007) Network effects and the dynamics of migration and inequality: theory and evidence from Mexico. J Dev Econ 84(1):1-24

McKenzie D, Rapoport H (2011) Can migration reduce educational attainment? Evidence from Mexico. J Popul Econ 24(4):1331-1358

McMillan MS, Rodrik D (2011) Globalization, Structural Change and Productivity Growth. NBER, Massachusetts Meng X (2001) The Informal Sector and Rural-urban Migration - A Chinese Case Study". Asian Econ J 15(1):71-89

Mitra A (2004) "Informal Sector, Networks and Intra-City Variations in Activities: Findings from Delhi Slums". Appl Reg Sci Conf, RURDS 16(2):154-169

Mitra A (2008) The Indian Labour Market: An Overview. ILO Asia-Pacific Working Paper Series, New Delhi

National Sample Survey Office (2012) Informal Sector and Conditions of Employment in India. NSS 66th Round, July 2009-June 2010, National Statistical Organisation, Ministry of Statistics and Programme Implementation, Government of India

Perry GE, Maloney WF, Arias OS, Fajnzylber P, Mason AD, Saavedra-Chanduvi J (2007) Informality: Exit and exclusion. The World Bank, Washington DC

Schneider F, Andreas B, Montenegro CE (2010) "Shadow Economies All over the World". World Bank Policy Research Working Paper 5356 
Sengupta AK (2009) The Challenge of Employment in India: An Informal Economy Perspective, . Report of the National Commission for Enterprises in the Unorganised Sector, Government of India, Volumes 1 and 2, Academic Foundation, New Delhi

Weeks J (1975) Policies for Expanding Employment in the Informal Urban Sector of Developing Economies". Int Labour Rev 111:1-13

Woodruff C, Zenteno RM (2007) Remittances and micro-enterprises in Mexico. J Dev Econ 82(2):509-528

10.1186/2193-9020-3-9

Cite this article as: Shonchoy and Junankar: The informal labour market in India: transitory or permanent employment for migrants? IZA Journal of Labor \& Development 2014, 3:9

Submit your manuscript to a SpringerOpen ${ }^{\odot}$ journal and benefit from:

- Convenient online submission

- Rigorous peer review

- Immediate publication on acceptance

- Open access: articles freely available online

- High visibility within the field

- Retaining the copyright to your article 